\title{
IDENTIFICAÇÃO E ANÁLISE DE DEPÓSITOS TECNOGÊNICOS NO PERÍMETRO URBANO DE PELOTAS (RS)
}

\author{
Flavio Almansa Baumbach' \\ Márlon Roxo Madeira ${ }^{2}$ \\ Marília Silva da Costa \\ Ricardo Brandolt de Jesus ${ }^{4}$ \\ Adriano Luís Heck Simon ${ }^{5}$
}

\begin{abstract}
Resumo: Este trabalho foi desenvolvido com o objetivo de identificar, classificar e caracterizar exemplos de depósitos tecnogênicos que ocorrem no perímetro urbano de Pelotas (RS), a fim de compreender as especificidades da ação humana enquanto agente geomorfológico. Foram identificados previamente 13 pontos de ocorrência de depósitos tecnogênicos em diferentes locais do perímetro urbano de Pelotas para reconhecimento em campo. A classificação e caracterização em campo se deu a partir de uma chave de classificação elaborada de acordo com a proposta de Peloggia (1999) e adaptações de Silva et al. (2014). Foram identificadas tipologias de depósitos tecnogênicos de todas as gêneses, com predomínio de depósitos construídos e induzidos. A diversidade dos depósitos tecnogênicos identificados demonstra a complexidade dos mecanismos de controle antrópico sobre ambientes úmidos na área em estudo e demanda providências por parte do poder público em pontos críticos onde a existência destes depósitos pode gerar impactos ambientais de maior magnitude.
\end{abstract}

Palavras-chave: ação antrópica; geomorfologia antropogênica; tecnógeno.

\section{IDENTIFICATION AND ANALISYS OF TECHNOGENIC DEPOSITS IN THE URBAN AREA OF PELOTAS (RS)}

\begin{abstract}
This work aimed to identify, to classify and to characterize examples of anthropogenic deposits in the urban area of Pelotas (RS) trying to find out the conditions of human action as geomorphological agent. Thirteen samples of technogenic deposits were previously identified in different spots of the urban area of Pelotas for field recognition. The field classification and characterization of the anthropogenic deposits were performed from a classification key structured from the proposals of Peloggia (1999) and adaptations from Silva et al. (2014). Technogenic deposits from all the typologies were identified, with the predominance of built and

\footnotetext{
${ }^{1}$ Programa de Pós-graduação em Arquitetura e Urbanismo da Universidade Federal de Pelotas. flavio.baumbach@gmail.com

${ }^{2}$ Bacharel em Geografia pela Universidade Federal de Pelotas. marlonmadeira@hotmail.com

${ }^{3}$ Programa de Pós-graduação em Geografia da Universidade Federal de Rio Grande. mariliacosta_bio@hotmail.com

${ }^{4}$ Programa de Pós-graduação em Geografia da Universidade Federal de Pelotas. brandolt.ric@hotmail.com

${ }^{5}$ Docente do Programa de Pós-graduação em Geografia daUniversidade Federal de Pelotas. adriano.simon@ufpel.edu.br
} 
induced deposits. The diversity of the identified technogenic deposits shows the complexity of the anthropic control mechanisms over the wetlands of the study area. This scenario demands the intervention of public power, especially in critical points where these deposits can generate or increase environmental impacts.

Keywords: anthropic action; anthropogenic geomorphology; technogene.

\section{INTRODUÇÃO}

A modificação das paisagens por meio de distintas formas de ocupação e usos da terra, provoca alterações na dinâmica dos sistemas físico-ambientais, causando interferências nas escalas temporais e espaciais de ocorrência dos fenômenos naturais (PEREZ FILHO; QUARESMA, 2006). Dessa forma, processos e formas que ocorreriam na escala de tempo geológica passam a ter condições de se manifestarem na escala de tempo histórica do homem (PEREZ FILHO; QUARESMA; 2011). Hoje se defende a ideia de que ocorrem processos geomorfológicos com gênese antrópica e ao conjunto de ações do homem sobre a superfície da Terra denomina-se tecnogênese (PELOGGIA, 1997).

A ação humana sobre os elementos dos sistemas geomorfológicos altera a dinâmica dos processos naturais, remodelando as formas de relevo e reordenando o fluxo de matéria e energia nesse sistema, sendo que atualmente cientistas defendem que vivemos um novo período geológico, denominado pelas geociências como Quinário ou Tecnógeno (PELOGGIA, 1997). O Tecnógeno, proposto por TerStepanian (1988), sinaliza a transição entre os períodos Quaternário e Quinário. Para Oliveira (1990, p. 412), o Quinário ou Tecnógeno se caracteriza como "o período em que a atividade humana passa a ser qualitativamente diferenciada da atividade biológica na modelagem da biosfera, desencadeando processos tecnogênicos cujas intensidades superam em muito os processos naturais".

A distribuição dos fenômenos tecnogênicos sobre a Terra não ocorre de maneira uniforme (PELOGGIA, 1997). Assim como a Revolução Neolítica apresentou discrepância temporal estratigráfica, o período de transição entre o Quaternário e o Quinário não pode ser considerado homogêneo devido às diferenças de desenvolvimento social e econômico, bem como das técnicas utilizadas nos diversos territórios do planeta (PEREZ FILHO; QUARESMA, 2011). Dessa forma é possível afirmar que alguns lugares da superfície terrestre vivem o Tecnógeno enquanto outros mantêm processos e dinâmicas mais atrelados ao Quaternário.

Peloggia (1997, p. 265) declara que é "nas concentrações urbanas que a ação modificadora do homem sobre a natureza, por assim dizer, geológica, se amplia e diversifica", evidenciando estes ambientes como os principais espaços de organização de morfologias antropogênicas caracterizadas pelos depósitos tecnogênicos.

Para Casseti (2005) o crescimento demográfico e a expansão das áreas urbanas estão associados à subordinação dos processos naturais à escala do tempo histórica e ao conjunto de mecanismos de controle diretos e indiretos empregados para a organização espacial e expansão do espaço urbano. Por meio do uso das técnicas, o homem se torna capaz de modificar, de forma expressiva, os elementos e os fenômenos pertencentes aos sistemas físico-ambientais na intenção de diminuir seus obstáculos e controlá-los (PEREZ FILHO; QUARESMA, 2011).

Peloggia (2018) destaca que as modificações que reconfiguram de forma intensa e extensiva as áreas urbanas provocam impactos ambientais significativos. 
Estes impactos não ocorrem da mesma forma em todas as áreas onde se manifestam os processos de expansão urbana, estabelecendo a todo o momento a associação entre a urbanização e as repercussões que a atividade humana desencadeia sobre os processos geomorfológicos, e consequentemente, o desenvolvimento de depósitos tecnogênicos.

De acordo com Oliveira et al. (2014) os registros deixados na superfície pela ação antrópica, oriundos de processos tecnológicos como terraplanagens e construções, e as marcas dos processos de degradação, como escorregamentos e erosões provocadas pelo uso da terra, seja ainda como deposição de sedimentos em fundos de vale ou por depósitos correlativos das degradações, são denominados depósitos tecnogênicos, e constituem testemunhos das ações antrópicas. Estes depósitos tecnogênicos gerados de forma direta ou indireta, gradativamente se integram na morfologia, principalmente em áreas de intensa urbanização (PEREIRA, 2011).

O conceito de depósito tecnogênico foi introduzido por Chemekov (1983), para fazer referência às distintas formações superficiais criadas como resultado de atividades antrópicas. Para Silva et al. (2014), os depósitos tecnogênicos são constituídos por materiais sedimentares acrescidos de artefatos diversos, resultantes de diversificadas práticas humanas desenvolvidas ao longo do tempo histórico. A introdução desses depósitos remodela a fisionomia e a fisiologia da paisagem de forma que altera o meio geológico-geomorfológico por meio do processo denominado geotecnogênese (PELOGGIA; OLIVEIRA, 2005).

Os depósitos tecnogênicos fazem parte da composição estrutural do relevo resultantes da expansão territorial, dos diferentes contextos socioeconômicos, da intensificação da produção de resíduos (orgânicos e/ou inorgânicos) e da mão de obra mecanizada (MIRANDOLA; MACEDO, 2014). Uma vez que compõem a camada superficial do terreno, o reconhecimento e a caracterização desses depósitos possibilita o entendimento das implicações da intervenção humana sobre a natureza, subsidiando, inclusive, planos de expansão urbana.

Dada à heterogeneidade destes materiais, a classificação dos ambientes de formação dos depósitos tecnogênicos torna-se uma tarefa complexa. Deve-se ponderar que estes depósitos são produtos da atividade humana e, portanto, sua classificação deve estar relacionada à ação desenvolvida em um dado ambiente e ao tipo de material encontrado (DIAS, 2015).

A classificação pioneira dos depósitos tecnogênicos no Brasil foi a proposta por Oliveira (1990), que classificou os mesmos em três principais tipos: depósitos acumulados (resultantes da atividade humana); depósitos modificados (depósitos naturais transformados pela ação humana) e depósitos induzidos (resultantes de processos naturais modificados). Peloggia (1999) propôs adaptações à classificação de Oliveira (1990), agrupando os três grupos iniciais em uma classe denominada de depósitos de primeira ordem (ou geração) e acrescentou uma segunda classe denominada depósitos de segunda ordem, incluindo os tipos de depósitos remobilizados (por exemplo, depósitos de fundo de vale criados por um deslizamento de terra de um antigo aterro na encosta da colina adjacente) e, ainda nesta classe, Nolasco (2002) considera os depósitos retrabalhados, (por exemplo, aterros que sofreram erosão).

Peloggia (1999) apresenta ainda um desdobramento da classificação proposta, que consiste na aplicação sequencial de cinco parâmetros de classificação dos depósitos tecnogênicos: gênese (identificação de processos de formação); composição (material constituinte); estrutura (modo de eliminação dos materiais no 
depósito); forma de ocorrência (formas de relevo relacionadas e posição geomorfológica) e ambiente tecnogênico (o contexto das práticas de uso da terra atreladas à produção e deposição do material tecnogênico).

A identificação, classificação e caracterização dos depósitos tecnogênicos em ambientes urbanos também deve considerar as condições físico-ambientais de organização destes espaços. Nas zonas urbanas localizadas em ambientes costeiros, os depósitos tecnogênicos se constituem em mecanismos de controle eficazes à expansão urbana e também atuam como feições antropogênicas que fragmentam as conexões sistêmicas entre os elementos da paisagem e alteram a dinâmica da morfohidrografia.

De acordo com Suguio (2003, apud HORN FILHO et al, 2014), a variedade dos ambientes costeiros do Brasil é grande, contando com uma rica diversidade biológica encontrada em praias, manguezais e recifes de corais, ambientes pressionados pela apropriação rápida e tecnificada, constituindo "prolongamentos do território", muitas vezes de forma não planejada. Peloggia (1999) explica que formas diretas de intervenção como obras de caráter corretivo (terraceamentos, preenchimentos ou compactações pedológicas com materiais de origem antrópica variada) agem como processos tecnogênicos (apud SILVA et al., 2014), podendo ser relacionados com a constituição da base para a maior parte dos assentamentos urbanos localizados em ambientes costeiros.

Silva (2013) utiliza a abordagem dos depósitos tecnogênicos para apontar a degradação geomorfológica das paisagens costeiras diante dos processos de urbanização, destacando os depósitos construídos sobre áreas de planície costeira em Florianópolis/SC. O autor aponta para o surgimento de impactos sociais e ambientais nos locais de ocorrência destes depósitos tecnogênicos, como o descarte de materiais úrbicos e gárbicos em planícies aluviais e lagunares inconsolidadas resultando na compactação das camadas pedológicas a ponto de receberem novas instalações urbanas.

A Planície Costeira do Rio Grande do Sul se caracteriza pelas superfícies com baixas amplitudes altimétricas, tendo sua paisagem lagunar e dunar constantemente alteradas pelos processos históricos de uso e ocupação da terra (LOPES et al., 2018), muitas vezes não equilibrados com os processos e dinâmicas naturais. De acordo com Tomazelli e Villwock (2000), a Planície Costeira Gaúcha é formada por "um amplo sistema de leques aluviais somados ao acréscimo lateral de quatro sistemas de deposição do tipo 'Laguna- Barreira'" (SILVA; REHBEIN, 2018) relacionados à Era Cenozóica. Entre estes depósitos se organizam complexos sistemas lagunares seccionados em três regiões distintas: o complexo de lagoas do litoral norte; o complexo da Laguna dos Patos; e o sistema das Lagoas MirimMangueira.

No recorte geomorfológico em que se encontra a área urbana de Pelotas, Selmo e Asmus (2006, apud SILVA e REHBEIN, 2018) destacam que a urbanização "avançou por ambientes paludiais e diminuiu a abrangência espacial das dunas, alterando aquíferos e habitats de reprodução de espécies animais". Silva e Rehbein, (2018), em estudo que abrange a área urbana de Pelotas, apontam para a existência de áreas de intervenção impermeabilizante inibidoras dos processos de percolação e lixiviação em regiões com função hidrológica natural como os terraços e planícies alúvio-coluvionares, semi-consolidadas ou inconsolidadas, apresentando fragilidades ambientais que ocasionam contratempos para as comunidades próximas às áreas de maiores intervenções (como a retilinização de canais de bairros centrais). Os autores citados apontam ainda que essas intervenções se constituem, inicialmente, 
como áreas de descarte de resíduos, passando por formas antrópicas de controle do fluxo das áreas úmidas, até resultar em sua função de assoalho para o assentamento urbano.

Diante destas considerações iniciais, este trabalho foi desenvolvido com o objetivo de identificar, classificar a caracterizar exemplos de depósitos tecnogênicos que ocorrem no perímetro urbano de Pelotas (RS), a fim de compreender as especificidades da ação humana enquanto agente geomorfológico na criação de formas do relevo e alteração das características e processos das áreas úmidas reconhecidas regionalmente como banhados.

\section{METODOLOGIA}

\section{LOCALIZAÇÃO E BREVE CARACTERIZAÇÃO DA ÁREA EM ESTUDO}

O município de Pelotas se localiza no extremo sul do estado do Rio Grande do Sul. Trata-se do terceiro município mais populoso do estado, com aproximadamente 341.648 habitantes e densidade demográfica de 203,89 hab/ $\mathrm{Km}^{2}$ (IBGE, 2018). O perímetro urbano possui uma área de $1.609 \mathrm{Km}^{2}$ e é dividido em sete regiões administrativas: Centro, Fragata, Barragem, Três Vendas, Areal, São Gonçalo e Laranjal (Figura $1 \mathrm{~A}$ ).

O processo de urbanização de Pelotas ocorreu ao longo das margens dos principais rios e arroios - locais que hoje são considerados Áreas de Preservação Permanente (APP's) - bem como sobre áreas úmidas denominadas regionalmente de banhados (PARFITT, 2002). A substituição destes ambientes naturais por estruturas construídas resultou na modificação do ciclo hidrológico local, tanto pela impermeabilização do solo, quanto pela ocupação às margens dos rios, ocasionando problemas na drenagem pluvial local (HANSMANN, 2013). Além disso, a topografia plana da cidade e a diminuição das áreas de banhado dificultam o escoamento pluvial, desencadeando alagamentos quando há precipitações intensas (XAVIER, 2010).

O perímetro urbano de Pelotas se assenta sob superfícies com altitude média de 7 metros em relação ao nível do mar, sendo limitado ao sul pelo Canal São Gonçalo, ao norte pelas superfícies dos terraços da Formação Graxaim, a oeste pela planície de inundação do Arroio Fragata e a leste pela Laguna dos Patos (XAVIER 2010). Os principais sistemas de drenagem da cidade correspondem aos arroios Santa Bárbara, Pepino e Pelotas, componentes da rede de macrodrenagem da cidade (DALTOÉ, 2015) (Figura 1 A e B).

A zona urbana está situada na província geomorfológica da Planície Costeira, caracterizada por apresentar uma extensa planície litorânea sedimentar que constitui a parte emersa da Bacia de Pelotas, associada a um vasto complexo lagunar (SILVA, 2007). Devido ao retrabalhamento flúvio-marinho, ocorrem rupturas de declive suaves e descontinuidades litopedológicas que compartimentam um relevo afeiçoado em unidades de terraços, dunas e planícies (TOMAZELLI; VILLWOCK, 2000). A articulação dos aspectos geológico-geomorfológicos com o clima subtropical úmido atual acentua processos pedogenéticos e biogeográficos que permitem uma biodiversidade abundante na região (PREFEITURA DE PELOTAS, 2013). 
Figura 1: Localização da área em estudo.

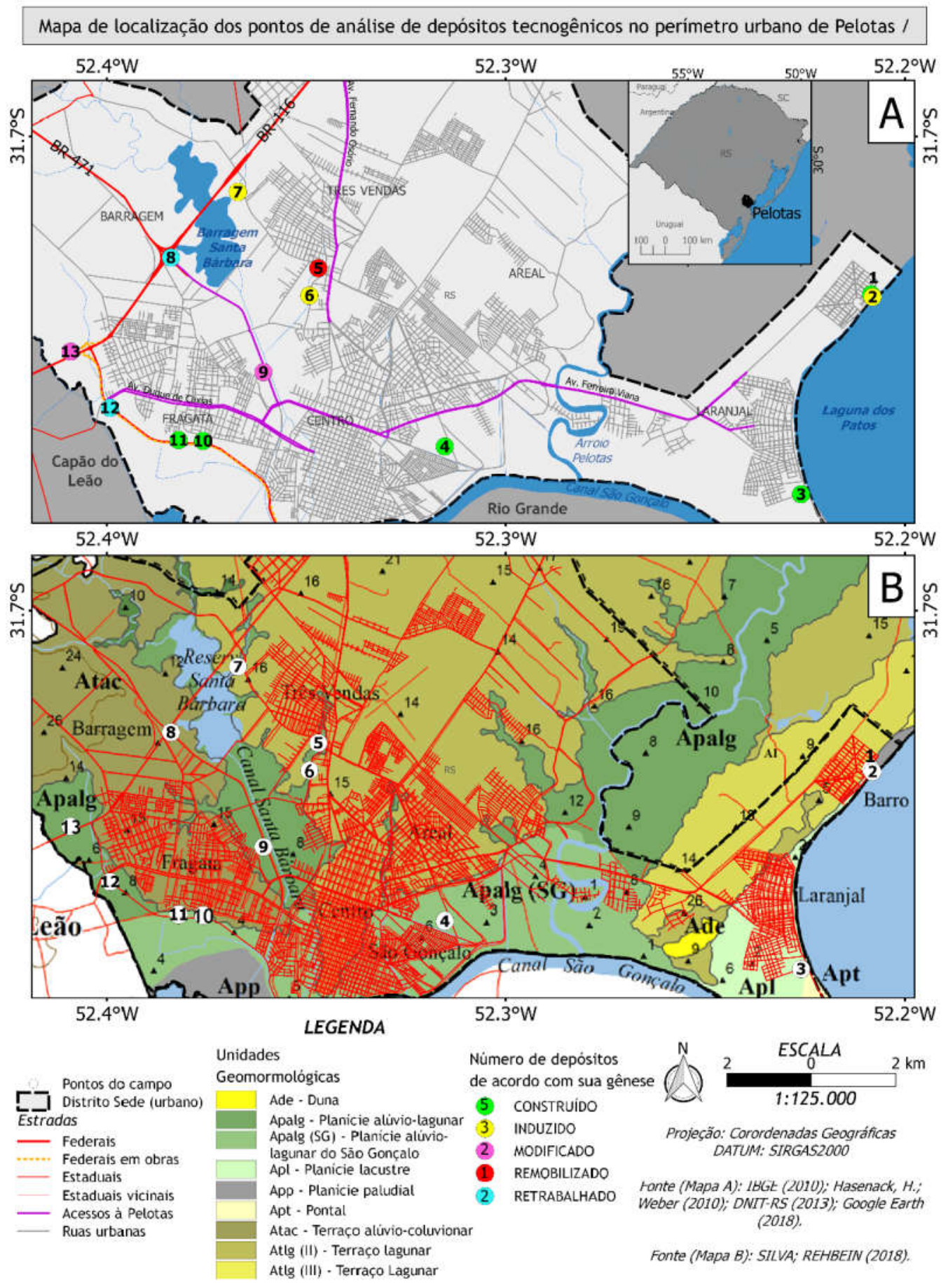

Fonte: autores, 2018. 


\section{IDENTIFICAÇÃO, CLASSIFICAÇÃO E CARACTERIZAÇÃO DE DEPÓSITOS TECNOGÊNICOS NO PERÍMETRO URBANO DE PELOTAS}

A fim de estabelecer o estado da arte da ação do Homem enquanto agente geomorfológico e sua influência na organização espacial de depósitos tecnogênicos, primeiramente foi realizada uma revisão das literaturas referentes as temáticas: Homem enquanto agente geomorfológico; Dinâmica de uso e ocupação em áreas urbanas; Formas de relevo antropogênicas; Depósitos tecnogênicos e organização/implicações dos depósitos tecnogênicos em áreas costeiras/litorâneas.

Em um segundo momento, foram identificados 13 pontos de ocorrência de depósitos tecnogênicos em diferentes locais do perímetro urbano de Pelotas (Figura 1 A). A identificação destes pontos ocorreu a partir do reconhecimento prévio da ocorrência dos mesmos por parte dos autores, com base na proposta teóricometodológicas de Peloggia (1999) e com o auxílio do software Google Earth Pro. A localização destes depósitos abrange pontos bem distribuídos dentro do perímetro urbano de Pelotas, em diferentes contextos das unidades geomorfológicas reconhecidas por Silva; Rehbein (2018) (Figura 1 B). Esta identificação preliminar se deu exatamente para orientar e validar a classificação em campo e para obter o maior número de tipologias de depósitos tecnogênicos que permitissem caracterizar a ação humana enquanto agente geológico-geomorfológico.

A classificação e caracterização em campo destes depósitos tecnogênicos previamente identificados se deu a partir de uma chave de classificação elaborada de acordo com a proposta de Peloggia (1999) e adaptações de Silva et al. (2014). A partir da chave de classificação considerou-se que os depósitos, identificados previamente em gabinete deveriam ser enquadrados, in situ, em diferentes tipologias (denominações) que variam de acordo com a gênese, o material constituinte, a estrutura, a forma de ocorrência e o ambiente tecnogênico (Quadro 1).

Quadro 1: Classificação dos depósitos tecnogênicos conforme Peloggia (1999).

\begin{tabular}{|c|c|c|c|c|}
\hline Gênese & Material Constituinte & Estrutura & $\begin{array}{l}\text { Forma de } \\
\text { Ocorrência }\end{array}$ & $\begin{array}{c}\text { Ambiente } \\
\text { Tecnogênico }\end{array}$ \\
\hline $\begin{array}{l}\text { 1. primeira } \\
\text { ordem } \\
\text { a) depósitos } \\
\text { construídos; } \\
\text { b) depósitos } \\
\text { induzidos; } \\
\text { c) depósitos } \\
\text { modificados; }\end{array}$ & $\begin{array}{l}\text { Materiais úrbicos: detritos urbanos } \\
\text { como tijolos, vidro, concreto, } \\
\text { asfalto, pregos, plástico, metais } \\
\text { diversos, pedra britada, etc. } \\
\text { Materiais gárbicos: são depósitos } \\
\text { de material detrítico com lixo } \\
\text { orgânico; Materiais espólicos: } \\
\text { materiais escavados e } \\
\text { redepositados por operações de } \\
\text { terraplanagem; } \\
\text { Materiais "líticos": materiais } \\
\text { terrosos provenientes da } \\
\text { dragagem de cursos d'água; }\end{array}$ & $\begin{array}{l}\text { Depósitos } \\
\text { estratificados: } \\
\text { estruturas } \\
\text { sedimentares } \\
\text { resultantes de } \\
\text { processos naturais ou } \\
\text { artificiais; } \\
\text { Depósitos } \\
\text { acamadados: } \\
\text { sobreposições } \\
\text { horizontais, com } \\
\text { características } \\
\text { distintas ou não; } \\
\text { Depósito em células: } \\
\text { os aterros sanitários; } \\
\text { Depósitos maciços: } \\
\text { características e }\end{array}$ & $\begin{array}{l}\text { Maciços } \\
\text { Isolados } \\
\text { Lençóis de } \\
\text { aterramento } \\
\text { Coluviformes } \\
\text { Aluviformes }\end{array}$ & $\begin{array}{l}\text { Industriais } \\
\text { Mineiros } \\
\text { Urbanos/peri- } \\
\text { urbanos } \\
\text { Rurais }\end{array}$ \\
\hline
\end{tabular}


Identificação e análise de depóstitos...

\begin{tabular}{|c|c|c|}
\hline $\begin{array}{l}\text { remobilizados; } \\
\text { b) depósitos } \\
\text { retrabalhados; }\end{array}$ & $\begin{array}{l}\text { natural; } \\
\text { Tecnogênico-aluvial: depósitos } \\
\text { constituídos por sedimentos } \\
\text { aluviais compostos por partículas } \\
\text { naturais e tecnogênicas. }\end{array}$ & $\begin{array}{l}\text { distribuição dos } \\
\text { materiais } \\
\text { homogêneos; } \\
\text { Depósitos irregulares, } \\
\text { quando o arranjo } \\
\text { interno é aleatório; }\end{array}$ \\
\hline
\end{tabular}

Fonte: Adaptados de Peloggia (1999) e Silva et al. (2014).

O trabalho de campo ocorreu no mês de novembro de 2018 , sob condições climáticas favoráveis. Durante o reconhecimento em campo foram utilizadas câmeras para registros fotográficos, trado para reconhecimento da estrutura subsuperficial dos depósitos tecnogênicos verificados, planilha com checklist para organização e reconhecimento de cada depósito tecnogênico visitado, Global Positioning System (GPS) para obtenção das coordenadas geográficas e posterior registro em Sistemas de Informação Geográfica (SIG).

A localização de cada um dos pontos identificados previamente em gabinete e reconhecidos em campo foi correlacionada com o Mapa Geomorfológico da Área de Influência da Planície Costeira proposto por Silva; Rehbein (2018) conforme Figura $1 \mathrm{~B}$, a fim de compreender sob quais unidades geomorfológicas os depósitos tecnogênicos estudados se assentam e quais as possíveis implicações destas localizações, dadas suas características e mecanismos de controle utilizados para sua organização.

Após o trabalho de campo, em gabinete, os depósitos tecnogênicos foram caracterizados e analisados. A caracterização seguiu a adaptação das orientações de Silva et al. (2014) que considerou: (a) as formas de ocorrência; (b) os ambientes de ocorrência; (c) possíveis estados de degradação ambiental e conflitos ambientais; (d) condições de continuidade do processo de organização do depósito ou necessidade de intervenção em função do impacto/degradação verificado, quando cabível.

\section{ANÁLISE DOS RESULTADOS}

Após a identificação preliminar dos pontos referentes aos depósitos tecnogênicos em gabinete e de sua verificação e caracterização em campo, foi possível realizar a classificação dos mesmos de acordo com cinco tipologias, sendo elas: cinco depósitos tecnogênicos construídos, três depósitos tecnogênicos induzidos, dois depósitos tecnogênicos modificados, um depósito tecnogênico remobilizado e dois depósitos tecnogênicos retrabalhados, abrangendo ao menos um exemplo de depósito para cada gênese proposta por Peloggia (1999). Estes depósitos foram analisados considerando ainda as derivações atreladas ao material constituinte, a estrutura, a forma de ocorrência e ao ambiente tecnogênico. Foram consideradas também as problemáticas relacionadas à localização destes depósitos tecnogênicos nas distintas unidades geomorfológicas que ocorrem no perímetro urbano de Pelotas.

\section{DEPÓSITOS CONSTRUÍDOS}

Depósitos construídos são "resultantes da ação humana direta, sendo caracterizados como aterros, corpos de rejeito, entre outros" (PELOGGIA, 1999, p. 
36). Dos pontos identificados em campo, cinco foram considerados como depósitos tecnogênicos construídos (Figura $1 \mathrm{~A}$ e B).

O Ponto 01 se encontra em zona de transição entre as Lombadas Costeiras (Al) vinculadas à Barreira Pleistocênica II e os depósitos de Planície Lacustre (Apl) (SILVA; REHBEIN, 2018). A localização do Ponto 01 em área de transição entre superfícies mais elevadas (lombada costeira) e superfícies mais baixas (faixa praial na planície lagunar) viabilizou a instalação de processos erosivos atrelados a retirada da cobertura vegetal e expansão da estrutura urbana do Balneário dos Prazeres. O levantamento realizado no Ponto 01 revelou um depósito construído com dois tempos diferentes de organização relacionados com a existência destas feições erosivas.

Num primeiro momento, no interior destas feições erosivas ocorreu a deposição irregular de resíduos domésticos orgânicos e inorgânicos, que se constituíram como um depósito tecnogênico construído, composto por material gárbico, estruturado de maneira irregular ou em células, sob forma de maciço isolado em ambiente peri-urbano (Figura 2).

A evolução dos processos erosivos e a constante deposição de detritos gárbicos levaram o poder público à consolidação de um Plano de Recuperação de Áreas Degradadas (PRAD) baseado no aterramento do processo erosivo inicial e dos depósitos gárbicos com material homogêneo, constituindo um depósito tecnogênico construído, composto por material espólico, estruturado em maciços, sob forma de lençol de aterramento em ambiente peri-urbano (Figura 3).

Figura 2: Resquícios de material gárbico que estava sob material espólico e que foi exumado por processos atuais de retrabalhamento posteriores ao PRAD.

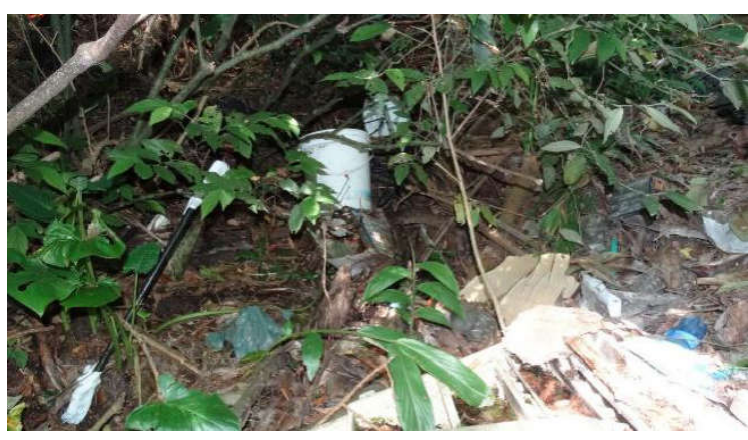

Fonte: autores, 2018.
Figura 3: Observam-se aspectos do material espólico depositado na ocasião da efetivação do PRAD (sobre os antigos depósitos gárbicos) e atualmente retrabalhado por sulcos erosivos.

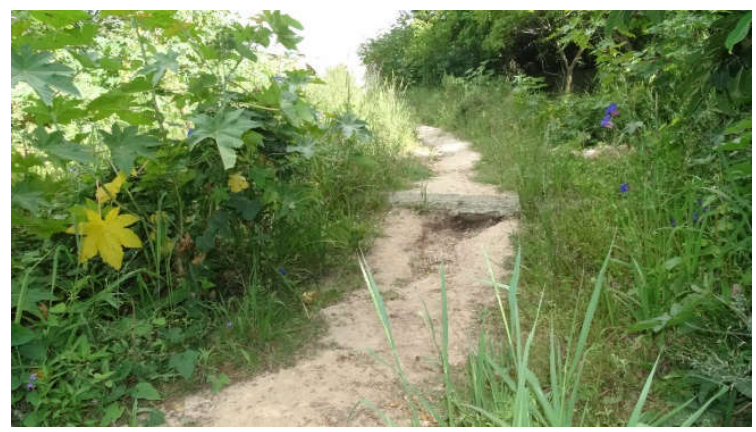

Fonte: autores, 2018.

Sobre o atual depósito construído espólico foi implantada cobertura vegetal para contenção dos processos erosivos. Atualmente, em função da constante circulação de pessoas e animais, a cobertura vegetal se encontra rarefeita viabilizando a formação de caminhos preferenciais onde se reinstalaram sulcos erosivos que, em situações mais extremas já se desenvolveram para ravinamentos (Figura 3). Isso evidencia a fragilidade dos depósitos tecnogênicos construídos em ambientes peri-urbanos, localizados sob condições geomorfológicas propícias à dinamização da ação dos agentes naturais que atuam no retrabalhamento deste 
material e possibilita a constatação de um terceiro momento deste depósito, associado ao seu retrabalhamento.

Os Pontos 03 e 04 constituem depósitos tecnogênicos construídos apenas com material espólico (Figura 1). O Ponto 03 é um depósito tecnogênico construído com material espólico estruturado de maneira maciça, sob forma de maciços isolados linearmente em ambiente peri-urbano (Figuras 4 e 5). Segundo Silva; Rehbein (2018) este depósito se encontra sobre superfície de Planície Lacustre (Apl). Trata-se de uma estrutura de engenharia em forma de talude, criada com o objetivo de proteger o ambiente urbano (instalado sobre áreas úmidas de planície lacustre) das cheias naturais periódicas.

Figura 4: Talude do depósito tecnogênico construído com material espólico.

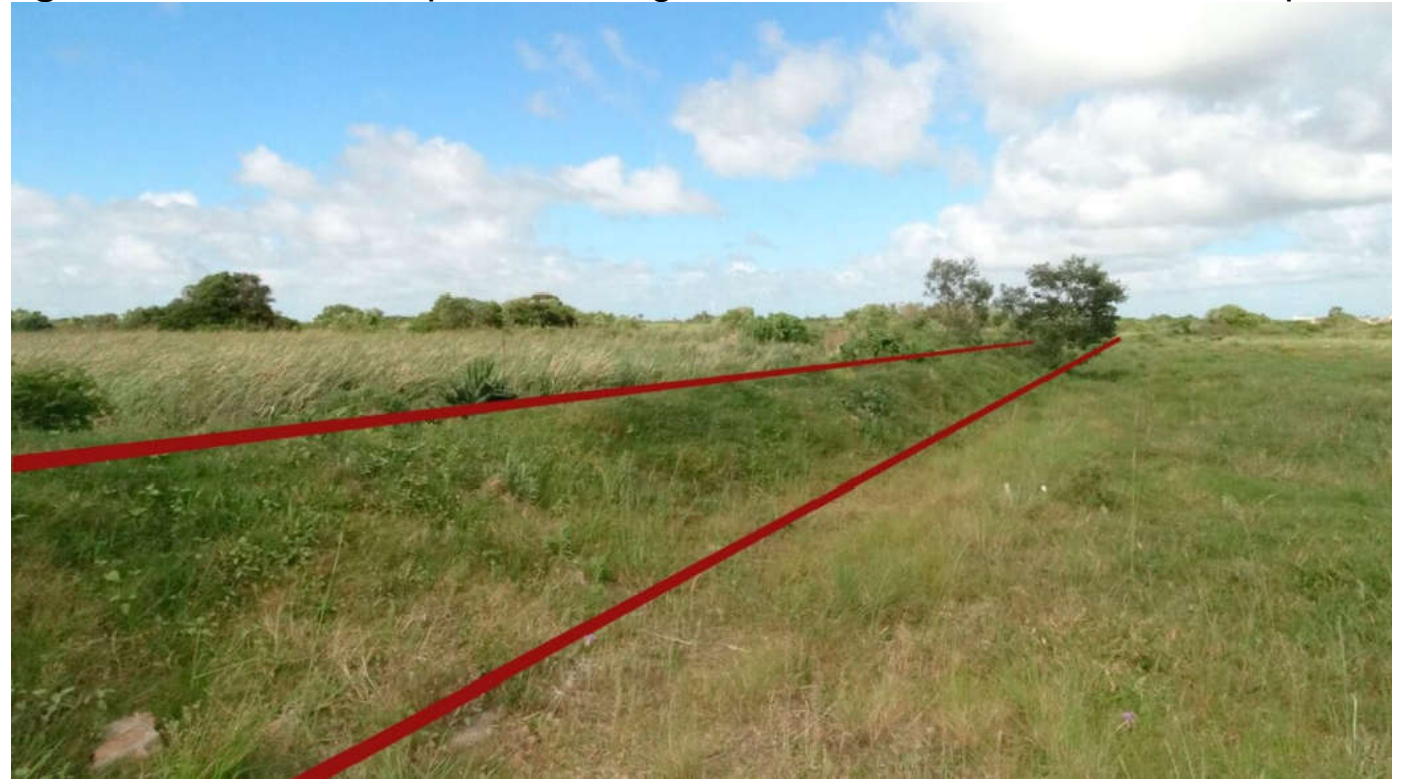

Fonte: dos autores, 2018.

Figura 5: Corte esquemático do talude (valores em metros).

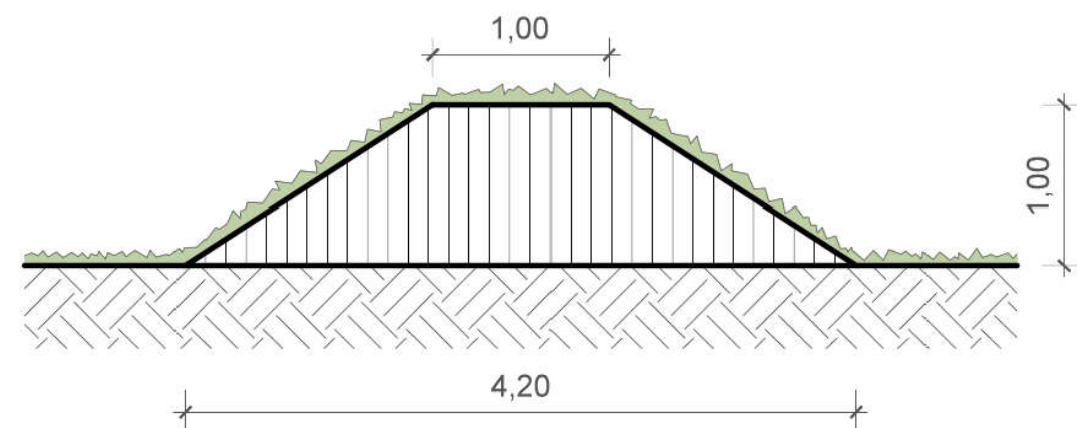

Fonte: dos autores, 2018.

Salienta-se que o depósito construído identificado como Ponto 03 se caracteriza como uma medida paliativa frente ao problema da consolidação urbana sobre áreas úmidas. O dique de contenção, como é chamado, foi construído no ano de 2015 a fim de conter o avanço da água da Laguna dos Patos e do Canal São Gonçalo sobre áreas de urbanização recente no Balneário do Laranjal. Tal projeto 
pode ser considerado mal planejado uma vez que remobilizou materiais paludais inconsolidados adjacentes para constituição deste depósito tecnogênico. Atualmente o depósito se encontra coberto por vegetação rasteira e com vários pontos em processo erosivo por meio de pequenos sulcos.

O Ponto 04 se caracteriza como um depósito tecnogênico construído espólico, estruturado de maneira maciça, sob forma de lençóis de aterramento em um ambiente urbano (Figuras 1 e 6 ). Este ponto se encontra sobre superfícies de Planície Alúvio-lagunar do São Gonçalo (Apalg-SG) (SILVA; REHBEIN, 2018) e se constitui em um aterramento para construção de empreendimento imobiliário de altopadrão.

Figura 6: Depósito tecnogênico construído com material espólico sobre área remanescente da Planície Alúvio-lagunar do São Gonçalo.

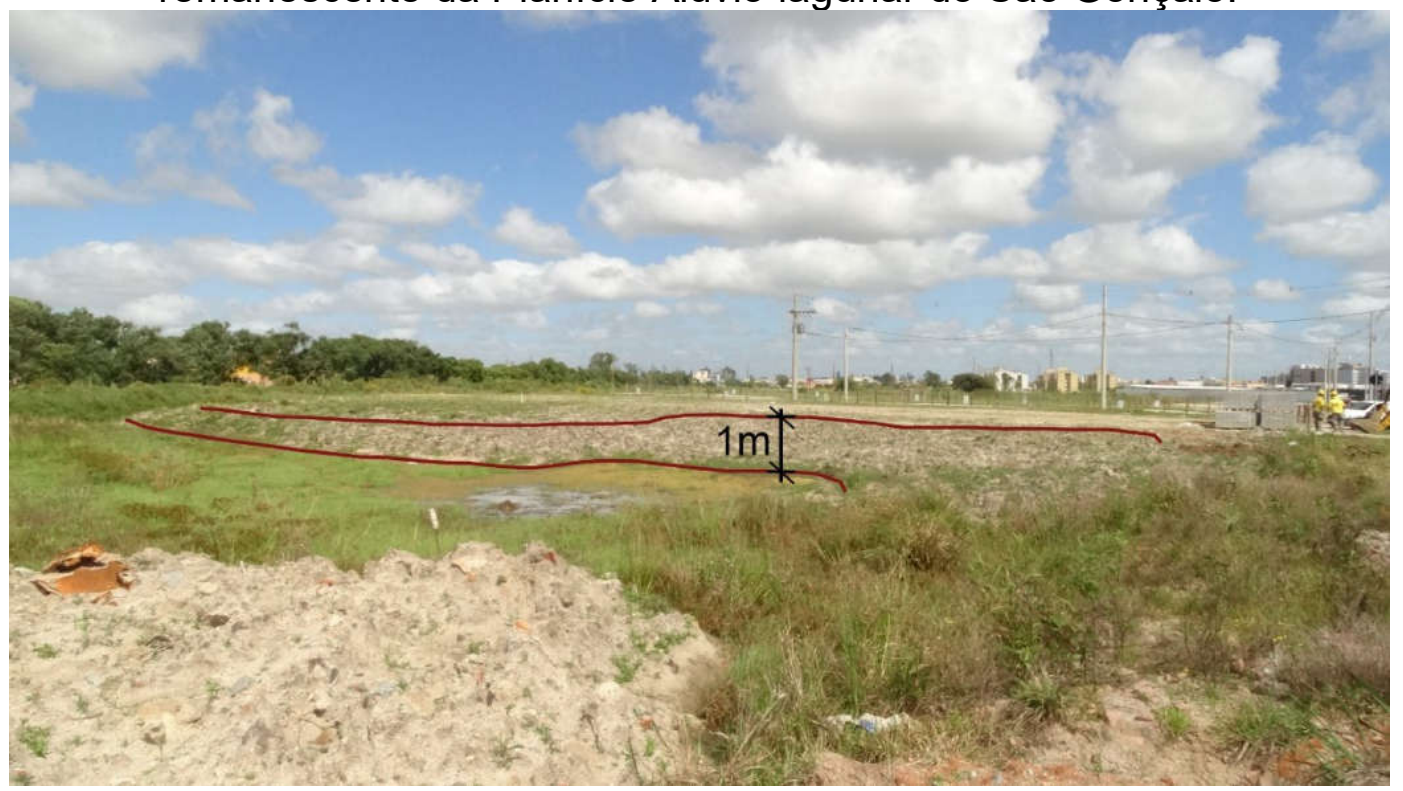

Fonte: autores, 2018.

Este setor da cidade, caracterizado naturalmente pela presença de áreas úmidas marginais ao Canal São Gonçalo, está em processo de aterramento para a construção de loteamentos destinados à expansão da zona urbana de Pelotas. Entretanto, áreas adjacentes a este empreendimento também têm sido consolidadas por meio desta tipologia de depósitos tecnogênicos causando uma constante segmentação e pressão dos remanescentes de áreas úmidas. Isto atua diretamente no escoamento e na concentração da água oriunda das precipitações periódicas, pois não tendo espaço suficiente para se acomodar por períodos prolongados causa implicações na drenagem de outros pontos do ambiente urbano, como por exemplo, a saturação de sistemas de escoamento pluvial, resultando em enchentes em outras áreas.

Os depósitos tecnogênicos identificados nos Pontos 10 e 11 têm a mesma origem. São depósitos construídos de material úrbico, estruturados de maneira acamada, sob forma de lençóis de aterramento. Entretanto, diferenças foram observadas no que se refere ao ambiente tecnogênico de organização destes depósitos: o Ponto 10 se encontra em área peri-urbana (Figura $7 \mathrm{~A}$ e B), ao passo que o Ponto 11 se encontra em área urbana, que recebeu uma superfície de material 
espólico, também acamado sob lençóis de aterramento, para possibilitar o uso da superfície para a construção civil (Figura 8 A e B).

Estes depósitos se localizam sobre superfícies de Planície Alúvio-lagunar do São Gonçalo (SG), ambiente caracterizado pela oscilação periódica do lençol freático em superfície (SILVA; REHBEIN, 2018). Tratam-se de depósitos resultantes da acumulação de materiais de entulho provenientes da construção civil. Muitos pontos de descarte de resíduos domésticos também são observados neste local.

No terreno que corresponde ao Ponto 10 se observa a presença de vegetação recobrindo parte do material úrbico (Figura $7 \mathrm{~A}$ ). Em campo, foi possível constatar a existência de locais mais rebaixados na superfície, com concentração de material com coloração mais escurecida, sugerindo áreas com escoamento subsuperficial mais rápido em função da heterogeneidade dos depósitos gárbicos em questão e de seus diferentes estágios de alteração e acomodação em subsuperfície (Figura 7B).

Figura 7A: Diversidade de resíduos úrbicos depositados no local: madeira, telhas, roupas, eletrodomésticos, etc. $\mathrm{O}$ crescimento da vegetação sugere intermitência no tempo de disposição destes materiais sobre o terreno.

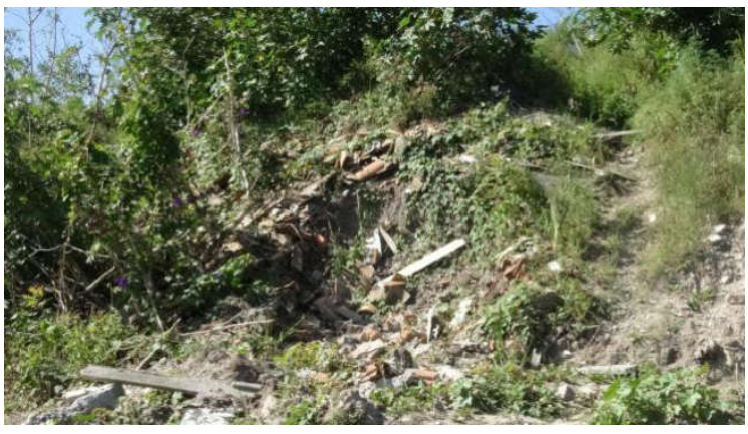

Fonte: autores, 2018.

Figura 8A: Áreas úmidas em processo de aterramento por materiais de origem úrbica.

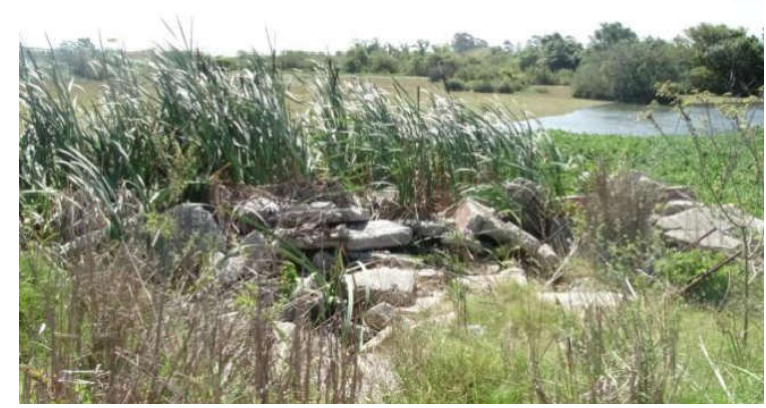

Fonte: autores, 2018.
Figura 7B: Superfícies rebaixadas em depósitos construídos úrbicos, onde ocorre concentração e infiltração mais rápida da água das precipitações.

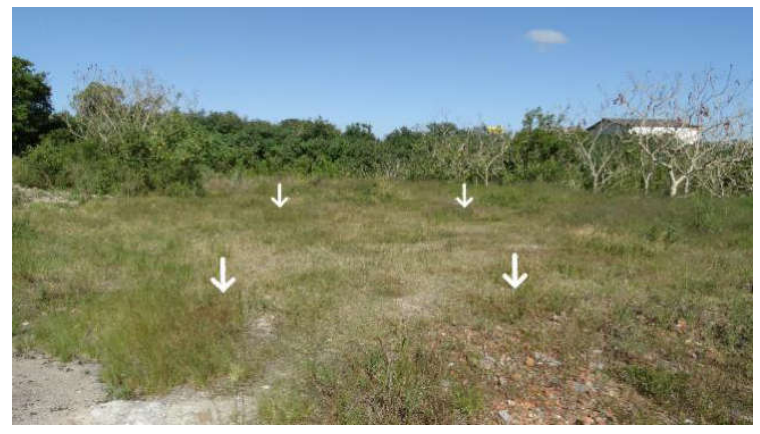

Fonte: autores, 2018.

Figura 8B: Loteamento consolidado sobre uma base composta por materiais úrbicos e superfície espólica.

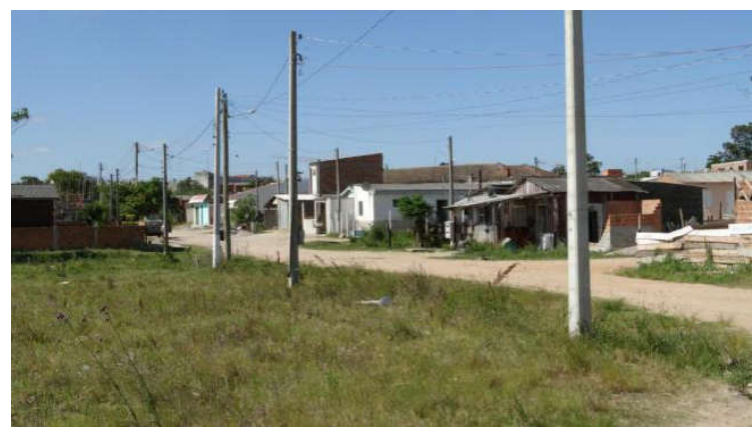

Fonte: autores, 2018.

Estes depósitos tecnogênicos estão sendo ampliados sobre Área de Preservação Permanente (APP). Como as áreas úmidas exercem função de reserva 
hídrica, auxiliam no ciclo hidrológico, e regulam a vazão e retenção temporária do excesso de água (GUASSELLI; SIMIONI, 2018), estes depósitos em expansão ficarão susceptíveis às inundações. Além disso, os diferentes tempos de decomposição dos materiais úrbicos irão se tornar um problema à medida que alguns materiais tendem a se decompor mais rapidamente fazendo com que o depósito ceda em pontos específicos comprometendo a estrutura física das casas no Ponto 11 (Figura 8B).

\section{DEPÓSITOS INDUZIDOS}

De acordo com Peloggia (1999), os depósitos tecnogênicos induzidos correspondem aos materiais "resultantes de processos naturais modificados ou intensificados pela ação humana, como depósitos de assoreamento, aluviões modernos, etc." (p. 36). Na área em estudo foram identificados e caracterizados três depósitos induzidos: os Pontos 02, 06 e 07 (Figura 1).

O levantamento realizado no Ponto 02 revelou um depósito tecnogênico induzido de material tecnogênico-aluvial, estruturado de maneira estratificada, sob forma aluviforme em ambiente peri-urbano constantemente retrabalhado pela morfodinâmica lagunar (Figura 9).

Este depósito se encontra sobre superfícies de faixa praial, correspondentes à unidade geomorfológica de Planície Lacustre (Apl) (SILVA; REHBEIN, 2018) e é induzido pelos atuais processos de retrabalhamento dos materiais gárbicos e espólicos oriundos dos depósitos construídos do Ponto 01 (Figuras 2 e 3).

Figura 9: Contato do canal pluvial com a Laguna dos Patos. Verifica-se as características dos depósitos induzidos com presença do material retrabalhado pela dinâmica lagunar predominando na superfície. A tradagem nesse local permitiu verificar a presença de sedimentos gárbicos nas camadas inferiores.

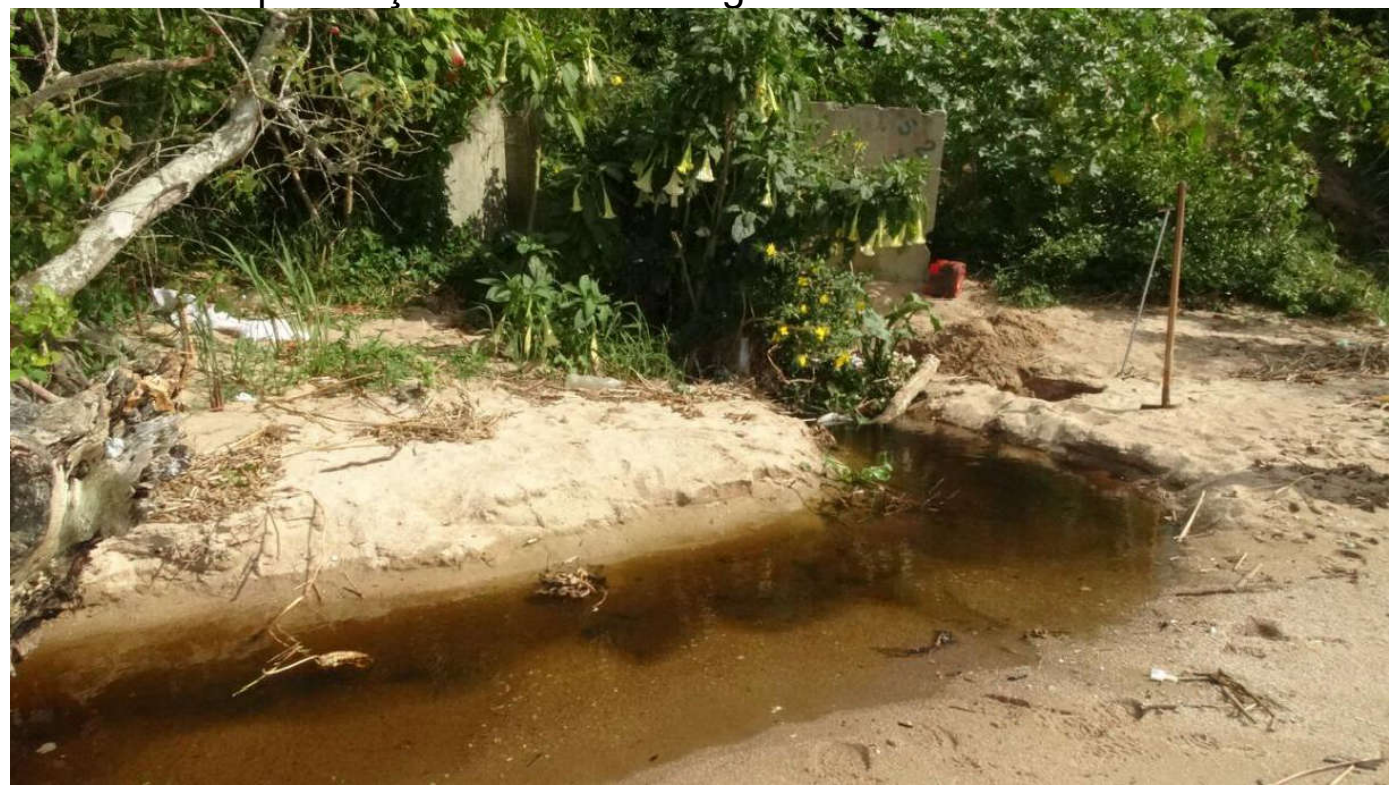

Fonte: autores, 2018.

Originalmente esta era uma área de contato entre o segmento final de um canal pluvial com a Laguna dos Patos. Este segmento final conduzia água oriunda das precipitações e sedimentos mais refinados em direção ao corpo lagunar. Com a evolução dos processos erosivos e conseqüente controle antrópico efetuado à 
montante (descrito no Ponto 01), criou-se um ambiente favorável à indução de depósitos tecnogênicos formados pelo retrabalhamento dos materiais gárbicos e espólicos encontrados nos depósitos tecnogênicos construídos à montante.

No levantamento realizado no Ponto 06, foi verificado um depósito tecnogênico induzido de material tecnogênico-aluvial, estruturado de maneira estratificada, sob forma aluviforme em ambiente peri-urbano. O depósito em questão se localiza em superfícies de Planície Alúvio-Lagunar (Apalg) de um curso afluente do Canal Santa Bárbara (SILVA; REHBEIN, 2018) (Figura 1 A e B), em uma área até então composta por coberturas vegetais secundárias e que atualmente se encontram alteradas devido a consolidação de um empreendimento imobiliário de alto padrão. Trata-se de um segmento de canal fluvial com características mais retilíneas, porém com baixa energia do fluxo, situação que possibilita a deposição dos sedimentos em bancos laterais e centrais verificados em campo (Figura 10). Esses bancos laterais e centrais podem ser caracterizados como depósitos tecnogênicos, visto que os mesmos são resultantes de processos erosivos naturais intensificados pela ação humana à montante.

Figura 10: Características do segmento de canal com perfil mais retilinizado e depósitos antropogênicos marginais e centrais. Destaque para a presença de coberturas vegetais nas margens desse segmento de canal.

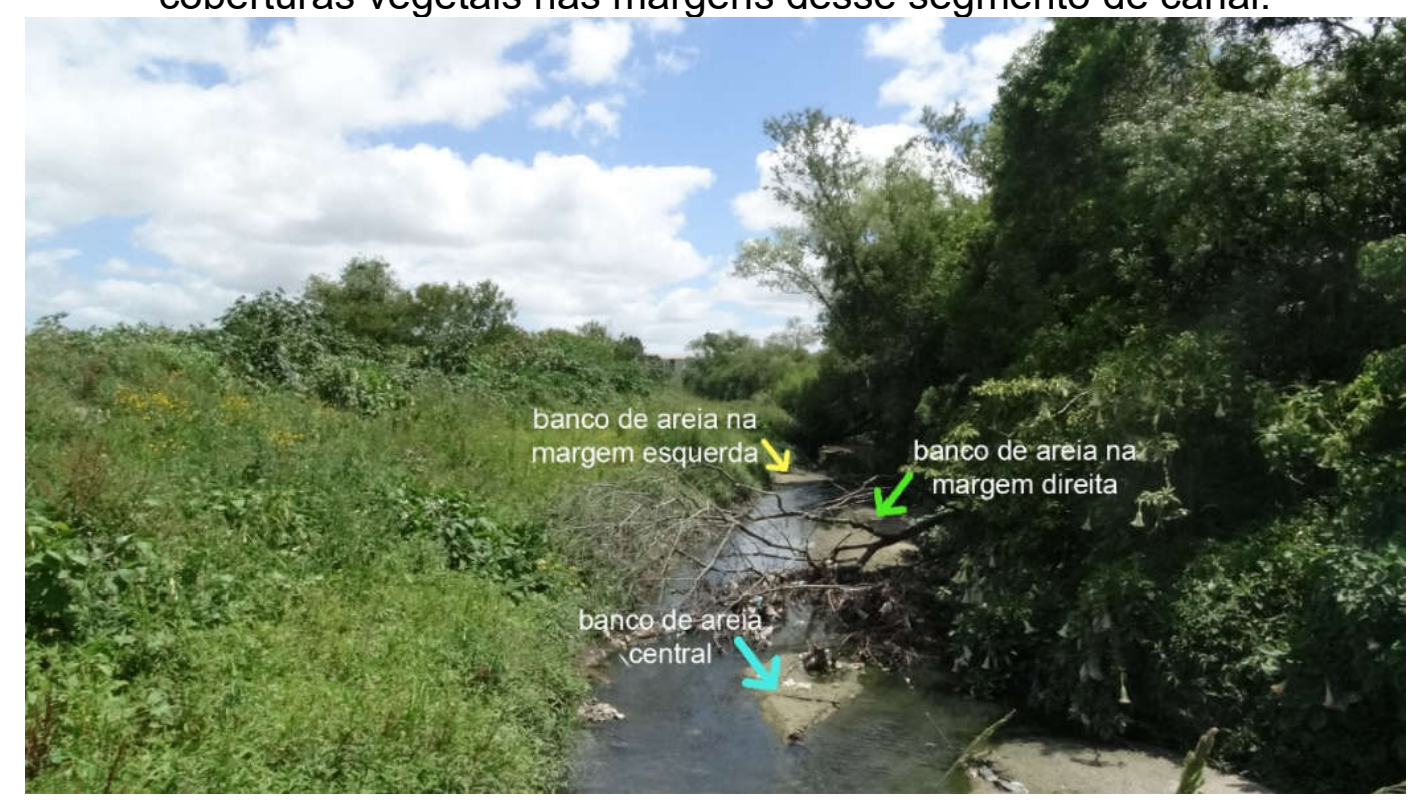

Fonte: autores, 2018.

Muito embora o ambiente onde os depósitos atrelados a este ponto ocorrem seja peri-urbano e exista cobertura vegetal nas margens do canal, a área fonte desse material tecnogênico-aluvial é prioritariamente oriunda de superfícies densamente urbanizadas localizadas à montante (Figura 1). Vale destacar que esse depósito se localiza em uma área onde está sendo construído um empreendimento imobiliário de alto padrão, fato que pode fazer com que esse ambiente mude nos cenários futuros gerando maior disponibilidade de material para atuação de processos erosivos.

O Ponto 07 se refere à um depósito tecnogênico induzido de material sedimentar, estruturado de maneira estratificada, sob forma aluvioforme em ambiente peri-urbano. Localiza-se em superfícies de Planície Aluvio-lagunar (Apalg) e corresponde a um afluente da margem esquerda do Reservatório Santa Bárbara, 
com nascentes localizadas à montante em superfícies de terraço lagunar que não ultrapassam 20 metros de altitude (Figura 1 A e B). O depósito se encontra em área de constante oscilação da lâmina d'água do Reservatório Santa Bárbara que corresponde a um nível de base local do canal fluvial em questão (Figura 11). Esse fato contribui para que o depósito se organize na forma de leque aluvial.

Figura 11: Organização do leque aluvial no contato entre o curso d'água e o reservatório Santa Bárbara em um anglo de visão da jusante para a montante localizado na outra margem do reservatório. Em (A) verifica-se o depósito aluviforme exposto na forma de leque aluvial. Em (B) verifica-se cobertura vegetal composta por macrófitas e vegetações arbustivas adaptadas ao estresse hídrico vinculado a variação da lâmina d'água do reservatório. $\mathrm{Em}(\mathrm{C})$, lâmina d'água com variação de 0,30 a $0,50 \mathrm{~cm}$ de profundidade.

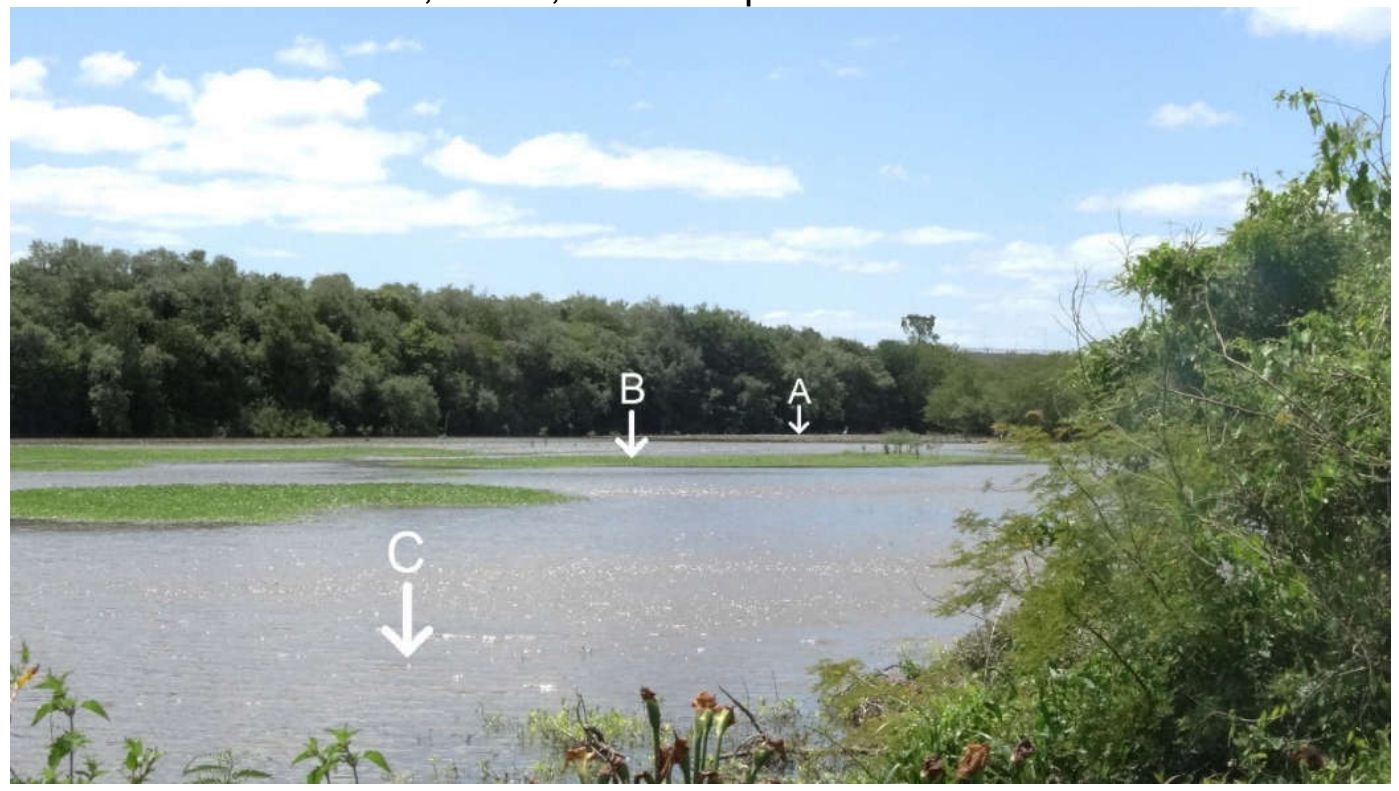

Fonte: autores, 2018.

Primeiramente cabe destacar que reservatórios constituem importantes mecanismos de controle que alteram os níveis de base dos canais fluviais, forçando uma maior deposição dos segmentos à montante. Este fator por si só já é responsável pela criação de depósitos tecnogênicos se considerarmos o tempo histórico envolvido na formação dos mesmos. No que se refere ao ponto em questão, o segmento de canal que deságua no Reservatório Santa Bárbara percorre áreas de cultivo de arroz irrigado nas imediações de suas nascentes, bem como áreas densamente urbanizadas em seu médio curso. Isso faz com que os sedimentos que adentram no reservatório sejam compostos, além de material arenoargiloso, também por artefatos tecnogênicos oriundos das estruturas urbanas e metais pesados contidos na água proveniente das lavouras de arroz irrigado (KORB; SUERTEGARAY, 2014).

\section{DEPÓSITOS MODIFICADOS}

Os depósitos tecnogênicos modificados se caracterizam, de acordo com Peloggia (1999, p. 36), como "solos ou depósitos naturais alterados em sua constituição por componentes tecnogênicos, como efluentes e adubos". Duas áreas 
foram identificadas e caracterizadas segundo esta tipologia: os Pontos 09 e 13 (Figura $1 \mathrm{~A}$ e B).

O Ponto 09 se caracteriza como um depósito tecnogênico modificado de material espólico, estruturado de maneira maciça e sob forma de maciço isolado em ambiente urbano. Este depósito está inserido na Planície Alúvio-Lagunar (Apalg), próximo da margem direita do Canal Santa Bárbara (SILVA; REHBEIN, 2018) (Figura 1). Localiza-se em ambiente urbano e se configura como uma lagoa de estabilização de esgoto criada para tratar os efluentes provenientes de loteamentos do Bairro Fragata. Anteriormente, este ambiente se caracterizava como uma área úmida (banhado), alterada por meio da remoção do material paludal para a constituição de uma lagoa artificial destinada à estabilização de efluentes que posteriormente são conduzidos ao Arroio Santa Bárbara (Figura 12).

Figura 12: Características gerais da lagoa de estabilização de efluentes: ao fundo da imagem é possível verificar as moradias do Bairro Fragata, bem como resquícios de vegetação nativa. Em (A) verificam-se os tanques da lagoa de estabilização e em

(B) um dos aterros que subdividem os tanques do sistema.

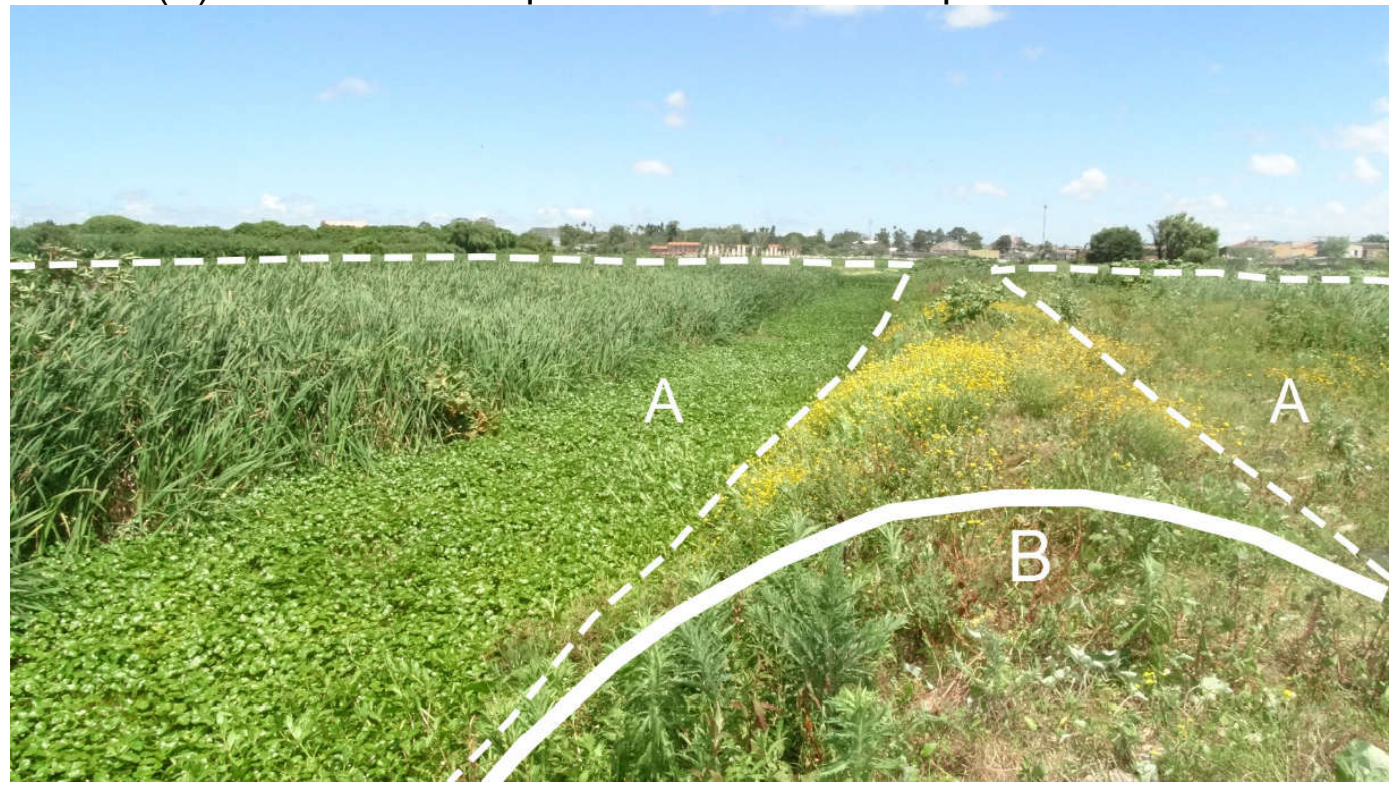

Fonte: autores, 2018.

Este depósito natural foi modificado para fins de recepção e estabilização dos efluentes das ocupações instaladas nas redondezas. A lagoa de estabilização de efluentes tem a função de propiciar um ambiente favorável para algas e bactérias para que as mesmas realizem a decomposição destes resíduos e desta forma, 0 efluente vindo das moradias próximas seja lançado para o canal Santa Bárbara e depois para o Canal São Gonçalo com um potencial menos degradante.

No Ponto 13 foi verificado um depósito tecnogênico modificado de material sedimentar, estruturado de maneira estratificada e aluvioforme em ambiente periurbano. O depósito em questão se localiza em superfícies de Planície Alúvio-lagunar (Apalg) marginais ao Arroio Fragata (SILVA; REHBEIN, 2018), onde é comum a ocorrência de aluviões associados à depósitos de planície lagunar e turfeiras (Figura 1). Nestas superfícies existe a oscilação periódica do lençol freático e a ocorrência de inundações causadas pelo Arroio Fragata. $O$ ambiente tecnogênico corresponde a áreas periurbanas onde se verificam usos agrícolas tradicionalmente voltados à 
lavoura de arroz irrigado e recentemente incorporados por lavouras de soja muito próximas dos espaços urbanos densamente ocupados (Figura 13).

Figura 13: Ao fundo, as matas de galeria que margeiam o Arroio Fragata. No centro, área de Planície Alúvio-lagunar com cobertura vegetal removida para a consolidação de práticas agrícolas originalmente voltadas ao arroz irrigado e atualmente destinadas ao plantio de soja. O maquinário agrícola evidencia as imposições tecnogênicas induzidas neste depósito. À esquerda verifica-se a presença de aterro antigo consolidado para a construção da BR 116, que secciona a Planície Alúviolagunar do Arroio Fragata. No primeiro plano, aspectos da cobertura vegetal original descaracterizada em área de contato com os terraços flúvio-lacustres.

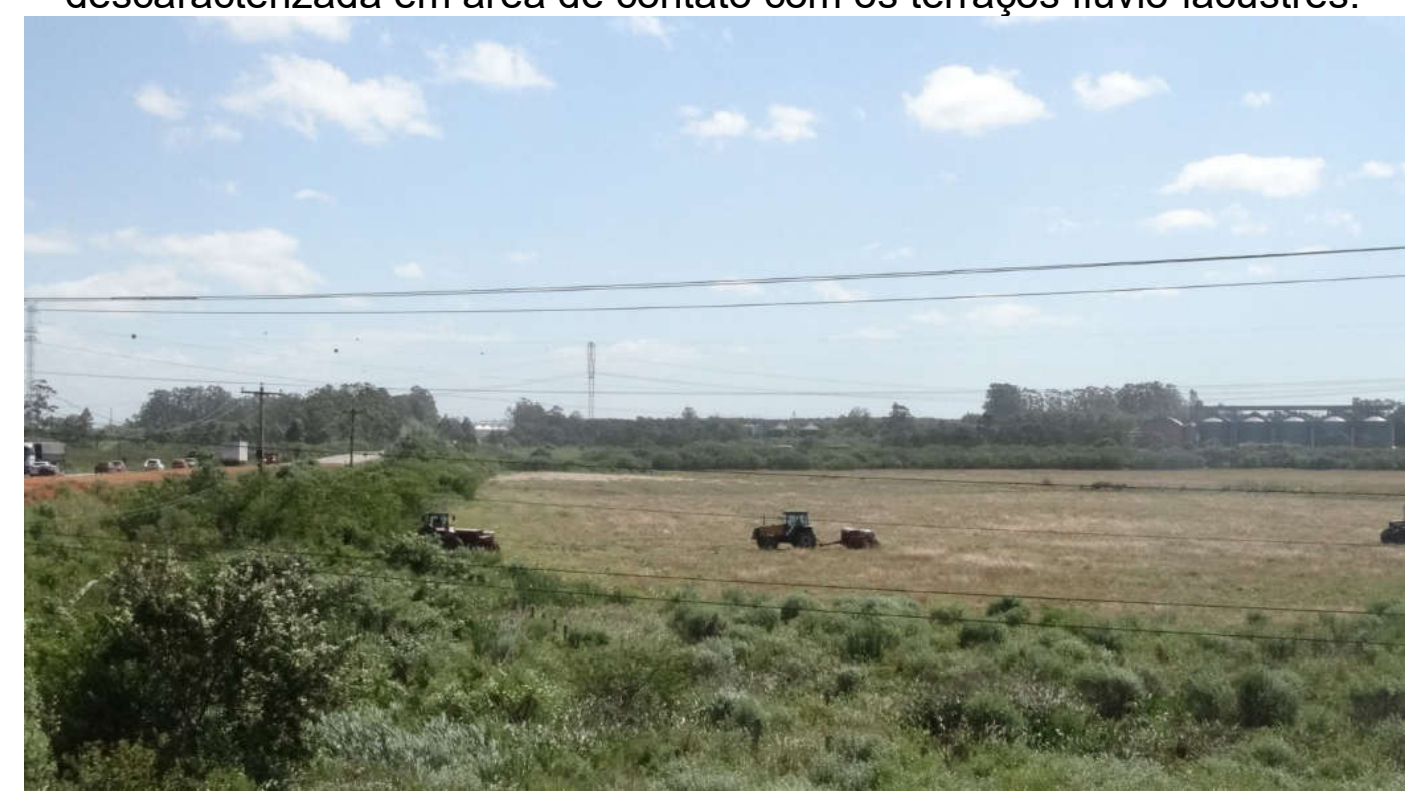

Fonte: autores, 2018.

De forma geral, as práticas agrícolas voltadas ao cultivo do arroz irrigado e da soja se fazem presentes nos espaços peri-urbanos da cidade de Pelotas e sobre depósitos aluviais e lagunares localizados em áreas de transição com o Planalto Sulrio-grandense. É comum que muitos espaços peri-urbanos de Pelotas (chácaras, propriedades de médio porte, empresas e vilas agrícolas incorporadas pela expansão urbana) estejam ainda atreladas a estas práticas agrícolas que se fazem sobre depósitos mais confinados e fragmentados. A ocorrência destas práticas agrícolas demanda intensa modificação dos aspectos do relevo e da hidrografia local, como a construção de terraços agrícolas, alteração do escoamento superficial e subsuperficial e da rede de drenagem para a consolidação das superfícies de cultivo de arroz e das lavouras de soja mais atuais. Por este motivo, compreende-se a modificação destes depósitos naturais por práticas e incorporação de insumos que descaracterizam a estrutura e os processos das Planícies Alúvio-lagunares em questão.

\section{DEPÓSITOS REMOBILIZADOS}

De acordo com Peloggia (1999, p. 38), os depósitos tecnogênicos remobilizados "são resultantes da remobilização espacial de outros depósitos tecnogênicos quaisquer, formando um novo depósito [...] como um depósito de fundo 
de vale formado pelo escorregamento de um aterro nas cabeceiras". Na área em estudo, o Ponto 05 corresponde a um depósito tecnogênico remobilizado, de material tecnogênico-aluvial, estruturado de maneira irregular, sob forma aluviforme em um ambiente urbano. O depósito em questão se localiza em superfícies de Planície Alúvio-lagunar (Apalg) de um curso afluente do Canal Santa Bárbara (SILVA; REHBEIN, 2018), em área densamente urbanizada da cidade de Pelotas (Figura 1 A e B). Processos de aprofundamento do leito puderam ser verificados em campo. Trata-se de um segmento sinuoso do canal formando margens côncavas (com tendência a erosão) e convexas (com tendência a deposição). É exatamente em uma das margens convexas que foi verificado o depósito em questão (Figura 14).

Figura 14: Depósito de fundo de vale, de caráter arenoso, mesclando materiais naturais e tecnogênicos, na margem convexa no segmento de canal fluvial.

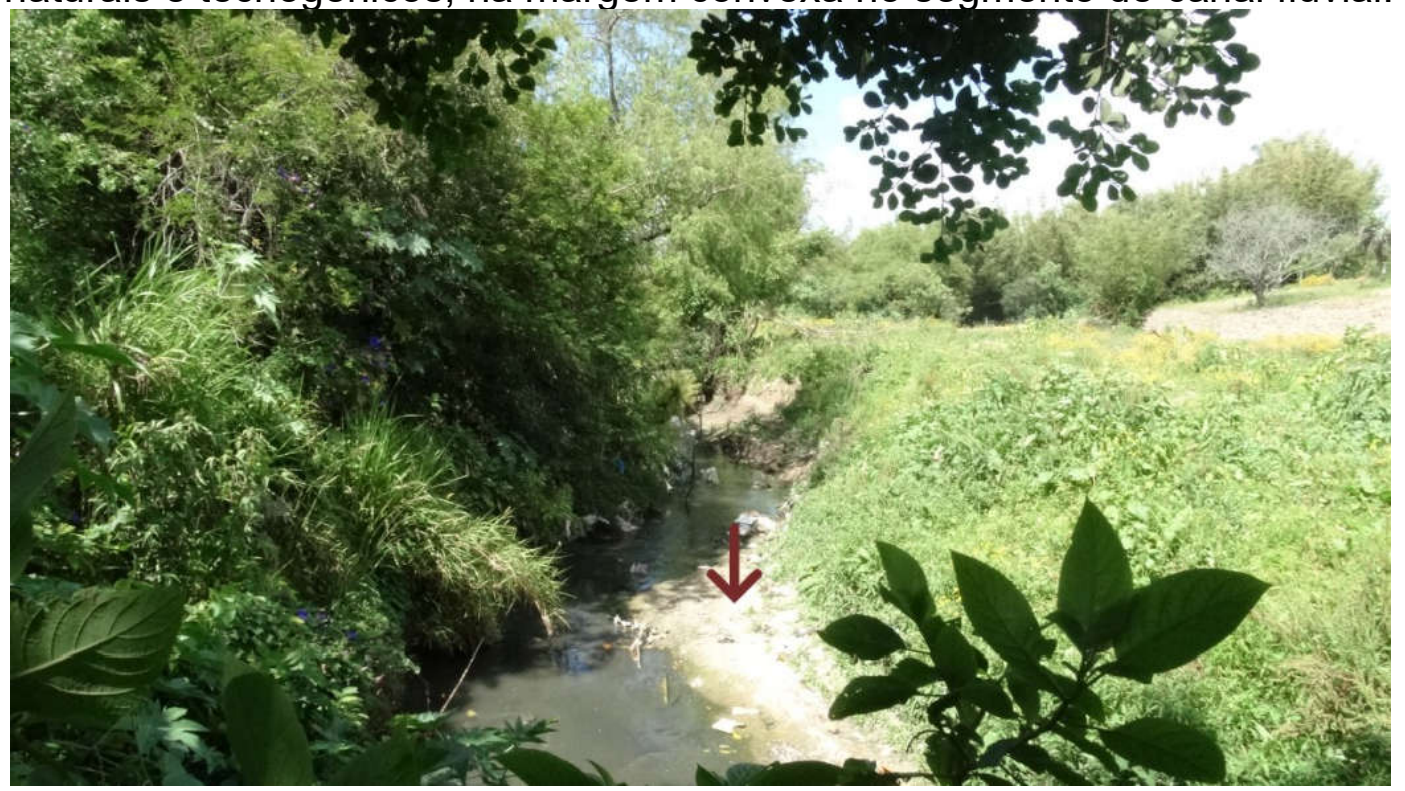

Fonte: autores, 2018.

Este depósito foi identificado em um ambiente tecnogênico urbano. O Canal que atravessa a região administrativa recebe diferentes pontos de emissão de efluentes domésticos, bem como descarte inadequado de resíduos que se mesclam com os depósitos aluviais que ocorrem ao longo deste segmento de canal, e que puderam ser identificados no arranjo interno aleatório do depósito em questão no momento da tradagem. Este canal fluvial é um exemplo de como a dinâmica de expansão urbana de Pelotas descaracterizou os principais cursos d'água, extinguindo grande parte deles e colaborando para a criação de ambientes antropogênicos, dotados de depósitos tecnogênicos nos canais que ainda permanecem.

Em uma das margens côncavas deste segmento de canal, imediatamente à montante do Ponto 05, foi identificado o que se convencionou chamar de depósito tecnogênico remobilizado de material tecnogênico-coluvional, estruturado de maneira irregular, sob forma de ocorrência coluviforme em ambiente urbano. Cabe destacar que o material constituinte deste depósito (tecnogênico-coluvional) não é apresentado na classificação de Peloggia (1999) (Quadro 1), entretanto a remobilização gravitacional desse conjunto sedimentar com presença de artefatos tecnogênicos pôde ser verificada como resultante de processos de solapamento 
basal que desestabilizaram o material sobrejacente depositando o mesmo na forma de colúvio na margem côncava do canal, conforme Figura 15.

Figura 15: (A) depósito de fundo de vale, de caráter arenoso, mesclando materiais naturais e tecnogênicos, na margem convexa no segmento de canal fluvial; (B) direção do fluxo do canal fluvial; (C) depósito tecnogênico-coluvional.

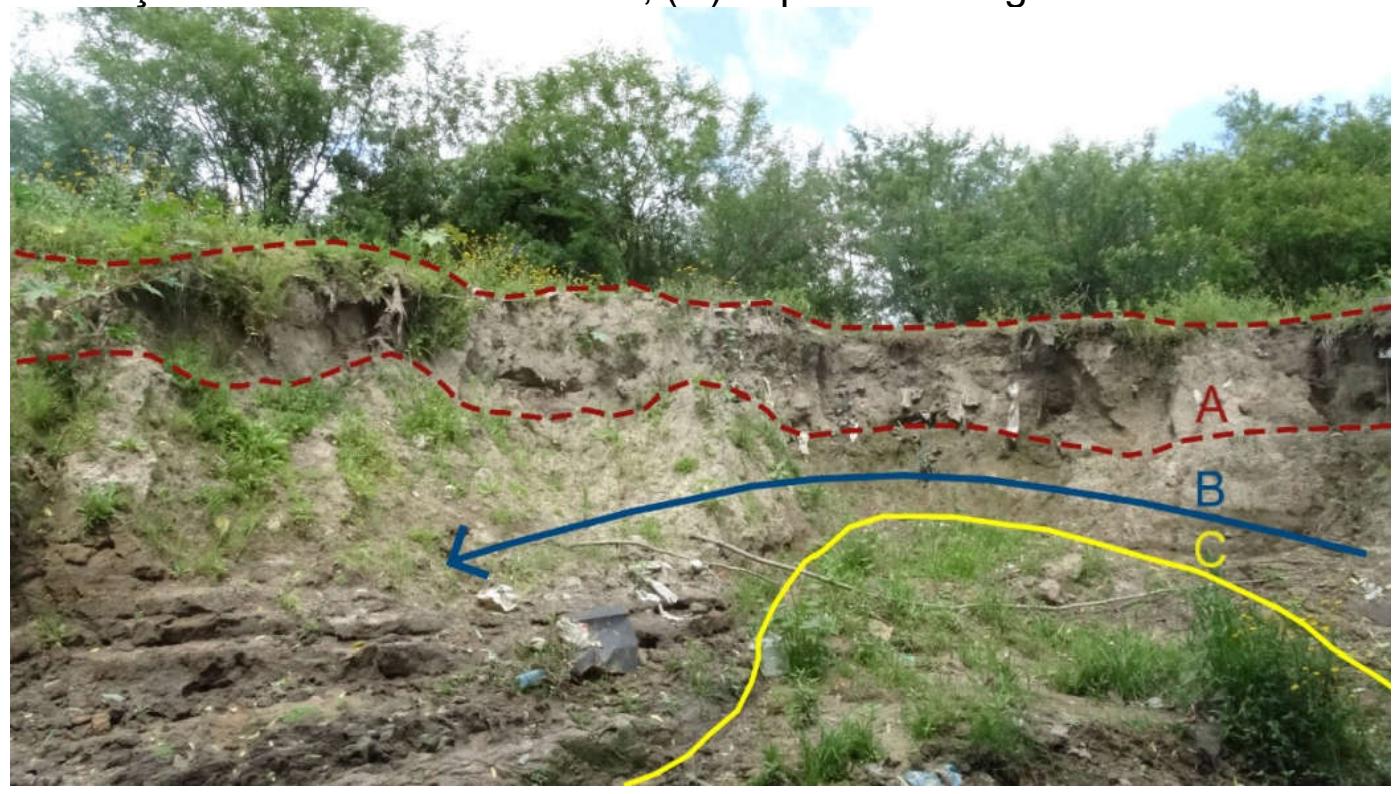

Fonte: autores, 2018.

\section{DEPÓSITOS RETRABALHADOS}

Os depósitos retrabalhados, de acordo com Peloggia (1999, p. 36),

[...] englobam qualquer depósito tecnogênico que sofreu a ação de agentes naturais, quando se impõem estruturas de outro agente geológico, sem intervenção humana [...] é o caso de um aterro que sofre processos como ravinamento, desagregação superficial, solapamento ou erosão interna após a sua construção

O Ponto 08 apresenta uma tipologia de depósito tecnogênico retrabalhado de material espólico, estruturado de maneira maciça, sob forma de maciços isolados linearmente em ambiente peri-urbano. O depósito em questão se localiza sobre superfícies de Terraço Alúvio-coluvionar (Atac) (SILVA; REHBEIN, 2018) (Figura 1 A e B). As superfícies de Terraço Alúvio-coluvionar correspondem às partes mais elevadas do sítio urbano de Pelotas, onde os processos de expansão urbana ocorrem de forma mais intensa. Sobre esses sistemas de terraço se encontra o depósito construído em questão, vinculado ao sistema de aterramentos e cortes implementados para a duplicação da BR 116 entre os anos de 2012 e 2018 (Figura 16). 
Figura 16: Processos erosivos associados ao escoamento da água pluvial.

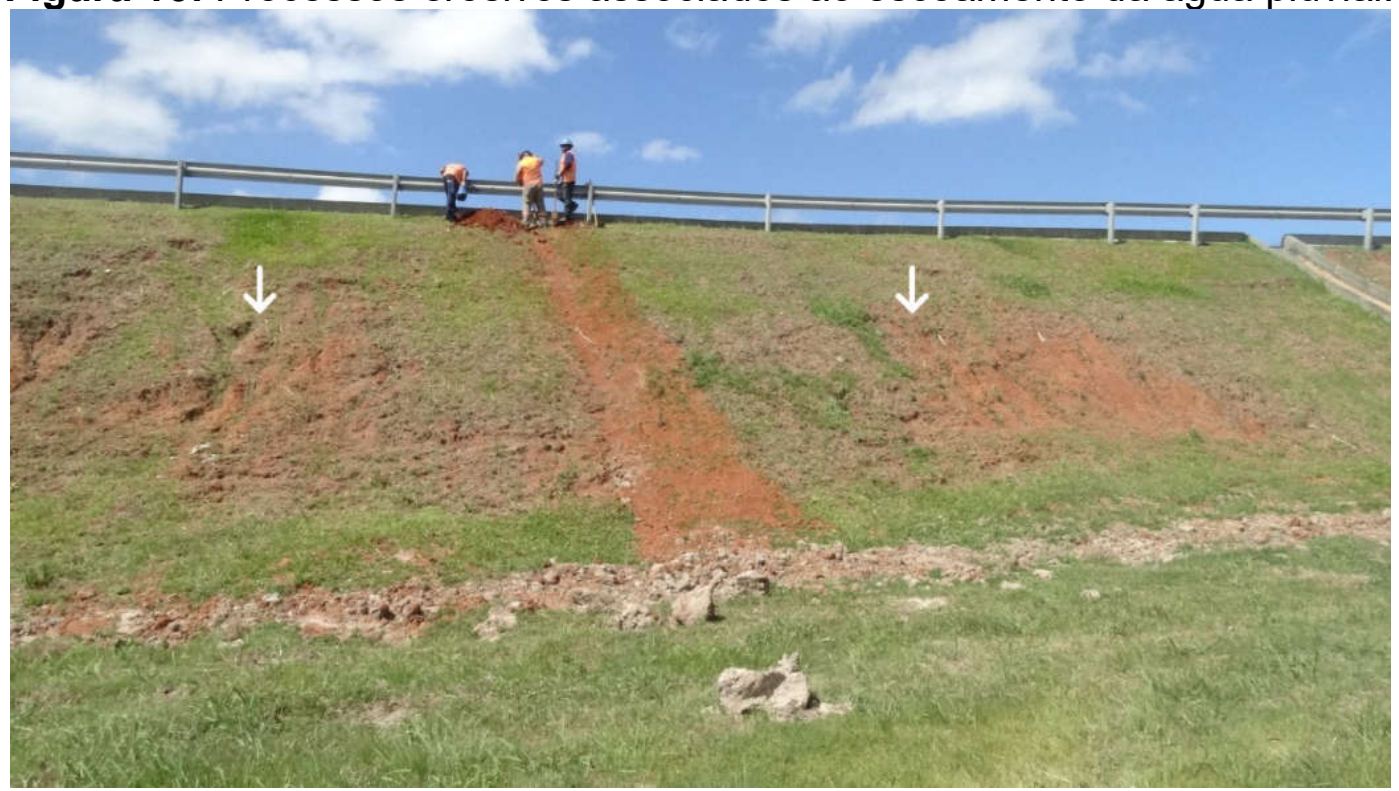

Fonte: autores, 2018.

Trata-se de um depósito tecnogênico originalmente construído, revestido por vegetação do tipo gramínea e atualmente exposto a atuação de processos erosivos que estão retrabalhando esse material e constituindo feições do tipo sulcos erosivos. Esse depósito tecnogênico evidencia que, mesmo com a tentativa de estabilização desse material, os processos plúvio-erosivos continuam ativos e podem ter relação com a declividade do talude, na qual foram constituídas estas morfologias antropogênicas.

O Ponto 12 apresenta uma tipologia de depósito tecnogênico retrabalhado de material espólico, estruturado de maneira maciça, sob forma de maciços isolados em ambiente urbano. Este depósito tecnogênico encontra-se sobre superfícies de Planície Alúvio-lagunar do São Gonçalo (Apalg - SG) (SILVA; REHBEIN, 2018) (Figura $1 \mathrm{~A}$ e B). Caracteriza-se como uma obra de engenharia não finalizada localizada em perímetro urbano construída para fins de duplicação da BR 116 e para viabilizar o acesso à cidade de Pelotas (Figura 17). 
Figura 17:Processos erosivos associados a eventos de escoamento pluvial atuando no retrabalhamento de depósito tecnogênico construído.



Fonte: autores, 2018

Este depósito tecnogênico foi construído através de materiais homogêneos, porém demonstra a suscetibilidade à erosão. Isto sugere que, em algum momento quando a obra estiver completamente finalizada, provavelmente poderão ocorrer novos sulcos e ravinamentos, o que colocará em risco a segurança da população que irá trafegar por este local, além de prejuízos financeiros e desperdício de material pela empresa responsável.

\section{CONSIDERAÇÕES FINAIS}

A variabilidade de gênese, material constituinte, estrutura e forma de ocorrência dos depósitos tecnogênicos identificados no perímetro urbano de Pelotas demonstra a diversidade dos mecanismos de controle antrópico utilizados para a expansão da estrutura urbana para o controle dos processos naturais.

Existe o predomínio na ocorrência destes depósitos tecnogênicos em unidades geomorfológicas atreladas às planícies (alúvio-lagunar e alúvio-lagunar do São Gonçalo). Historicamente os processos de expansão urbana de Pelotas ocorreram sobre estas superfícies e na atualidade a evolução dos loteamentos regulares e irregulares continua se ocupando destas unidades geomorfológicas que abrangem as áreas úmidas de banhados, considerados importantes ambientes de regulação hidrogeomorfológica e da biodiversidade regional.

Os depósitos tecnogênicos constituídos de material úrbico identificados nesta pesquisa estão geralmente associados às feições antropogênicas do tipo aterramentos, que vêm ocorrendo de forma generalizada no perímetro urbano de Pelotas. O comportamento pós-aterramento dos materiais heterogêneos constituintes destes depósitos ainda não é suficientemente compreendido. Isso pode colocar em risco muitas das estruturas urbanas (residências, arruamentos, 
canalizações e sistemas de rede elétrica) que se alocam sobre estes depósitos formados por materiais com estágios de alteração e acomodação diferenciados. Deve-se considerar ainda que estes depósitos de materiais úrbicos são acomodados predominantemente sobre diferentes unidades geomorfológicas que compõem a planície costeira na área urbana de Pelotas. Estas unidades geomorfológicas, de formação recente, se apresentam por vezes inconsolidadas e vulneráveis à expansão destes depósitos.

Depósitos tecnogênicos constituídos de material espólico e verificados nesta análise se apresentam como tendência na expansão de lotes urbanos de alto padrão ou na constituição de aterramentos vinculados às obras de engenharia, como construção/ampliação de rodovias. Mesmo caracterizados pelo uso de técnicas modernas de engenharia e de materiais homogêneos em sua constituição, verificouse que estes depósitos apresentam processos de retrabalhamento em todos os casos analisados. A perda de material causada pelo retrabalhamento pode implicar no soterramento de fragmentos de áreas úmidas e no assoreamento de canais fluviais adjacentes e até mesmo na perda de qualidade das obras para as quais estes depósitos foram construídos.

Por fim deve-se destacar que este é o primeiro estudo sobre depósitos tecnogênicos na cidade de Pelotas. Considerando que o levantamento realizado identificou todas as gêneses de depósitos tecnogênicos em pontos dispersos do perímetro urbano, ele deve ser o ponto inicial para a realização de estudos mais aprofundados sobre cada uma das tipologias e suas interferências específicas na dinâmica das unidades geomorfológicas e das áreas úmidas de banhado. Existem, entretanto, pontos críticos associados à estados de degradação e conflito ambiental que exigem providências imediatas por parte do poder público para que processos atrelados a existência destes depósitos tecnogênicos não se tornem impactos ambientais de maior magnitude. Este é o caso dos Pontos 01, 07, 10 e 11, descritos nesta pesquisa.

O Ponto 01 reflete a problemática associada à retirada de cobertura vegetal e à expansão urbana viabilizando a instalação de processos erosivos, que foram aterrados por materiais de origem gárbica que contribuíram para a aceleração do processo de erosão. Com o objetivo de controle, houve o aterramento com material espólico, tentativa não bem-sucedida de um PRAD, já que se trata de um local sob condições geomorfológicas propícias à dinamização da ação dos agentes naturais, que hoje atuam no retrabalhamento deste material;

O Ponto 07, segmento de canal fluvial que deságua no Reservatório Santa Bárbara percorre áreas de cultivo de arroz irrigado nas imediações de suas nascentes, bem como áreas densamente urbanizadas. Isso faz com que os sedimentos que adentram o reservatório sejam compostos, além de material arenoargiloso, também por artefatos tecnogênicos oriundos das estruturas urbanas e metais pesados contidos na água proveniente das lavouras de arroz irrigado. Esta situação pode estar ocorrendo nos demais exutório de canais fluviais no Reservatório Santa Bárbara, contribuindo para a diminuição do período de vida útil desse manancial de captação de água.

Os Pontos 10 e 11 estão localizados sobre ambiente caracterizado pela oscilação periódica do lençol freático em superfície, o que favorece a formação de banhados ou áreas úmidas, importantes para a reserva hídrica, ciclo hidrológico, e regular a vazão e retenção temporária do excesso de água. Uma vez que os depósitos estão sendo construídos sobre essas áreas, suprimindo todo o contexto original de banhado e vegetação nativa, os mesmos ficarão susceptíveis às 
inundações e a contaminação do lençol freático. Ademais, os diferentes tempos de decomposição dos materiais úrbicos irão se tornar um problema à medida que alguns materiais tendem a se decompor mais rapidamente do que outros, comprometendo a estrutura física das estruturas residenciais.

\section{REFERÊNCIAS}

CASSETI, V. Estrutura superficial. In: Valter Casseti. Elementos de

Geomorfologia, 2005. Disponível em: <http://www.funape.org.br/geomorfologia/>. Acesso em 29 de out. de 2018.

CHEMEKOV, Y. F. Technogenic deposits. In: INQUA Congress, 11, Moscow, Abstracts... v.3, p. 62. 1983.

DALTOÉ, M. F. Análise qualitativa de resíduos sólidos presentes nas redes de micro e macrodrenagem na cidade de Pelotas-RS. 2015. 88f. Trabalho de

Conclusão de Curso em Engenharia Ambiental e Sanitária - Universidade Federal de Pelotas (UFPel - RS, Brasil).

DIAS, M. B. G. Depósitos tecnogênicos na região noroeste de Goiânia (GO).

2015. 138f. Dissertação de Mestrado em Geografia - Universidade Estadual Paulista (Unesp - SP, Brasil).

GUASSELLI, L. A.; SIMIONI, J. P. D. Conceituação de áreas úmidas. Áreas úmidas: questões ambientais. Porto Alegre: UFRGS/Programa de Pós-graduação em Geografia, 2018. p. 11-31.

HANSMANN, H. Z. Descrição e caracterização das principais enchentes e alagamentos de Pelotas-RS. 2013. 63f. Trabalho de Conclusão de Curso em Engenharia Ambiental e Sanitária - Universidade Federal de Pelotas (UFPel - RS, Brasil).

HORN FILHO, N. O. et al. Estudo Geológico dos Depósitos Clásticos Quaternários Superficiais da Planície Costeira de Santa Catarina, Brasil. Gravel, v. 12, n. 1, p. 41107, 2014.

IBGE - Instituto Brasileiro de Geografia e Estatística. Disponível em:

$<$ https://cidades.ibge.gov.br/brasil/rs/pelotas/panorama> Acesso em $10 \mathrm{de} \mathrm{dez.} \mathrm{De}$

2018.

KORB, C. C.; SUERTEGARAY, D. M. A. Identificação de depósitos tecnogênicos em um reservatório de abastecimento de água da cidade de Pelotas

(RS). Quaternaryand Environmental Geosciences, v. 5, n. 1, p. 41-59, 2014. LOPES, E. B.; RUIZ, T. C. D.; DOS ANJOS, F. A. A ocupação urbana no Litoral Norte do Rio Grande do Sul, Brasil, e suas implicações no turismo de segunda residência. Revista Brasileira de Gestão Urbana, v. 10, n. 2, p. 426-441, 2018. MIRANDOLA, F. A.; MACEDO, E. S. Proposta de classificação do Tecnógeno para uso no mapeamento de áreas de risco de deslizamento. Quaternaryand Environmental Geosciences, v. 5, n. 1, p. 66-81, 2014. NOLASCO, M. C. Registros geológicos gerados pelo garimpo. Lavras Diamantinas - BA. 2002. 316f. Tese de Doutorado em Geociências - Universidade Federal do Rio Grande do Sul (UFRGS - RS, Brasil).

OLIVEIRA, A. M. S. Depósitos tecnogênicos associados à erosão atual. 1990. In: CONGRESSO BRASILEIRO DE GEOLOGIA E ENGENHARIA, Salvador... Anais, ABGE: ABMS, v.1, p.411-415. 
OLIVEIRA, A. A.; OLIVEIRA, A. M. S.; ANDRADE, M. R. M. Depósitos tecnogênicos como testemunhos e indicadores de processos geológicos em área urbana degradada em Guarulhos, SP. Quaternaryand Environmental Geosciences, v.5, n.1, p.12-27, 2014.

PARFITT, C. M. Impacto urbano em área de interesse e proteção ambiental. 2002. 238f. Dissertação de Mestrado em Planejamento Urbano e Regional Universidade Federal do Rio Grande do Sul (UFRGS - RS, Brasil).

PELOGGIA, A. U. G. A ação do homem enquanto ponto fundamental da geologia do Tecnógeno. Revista Brasileira de Geociências, v.27, n.3, 257-268, 1997. PELOGGIA, A. U. G. Sobre a classificação, enquadramento estratigráfico e cartografação dos solos e depósitos tecnogênicos. In: PELOGGIA, A. U. G. Manual Geotécnico 3: Estudos de Geotécnica e Geologia Urbana (I). São Paulo: [s.n.], 1999. p. 35-50.

PELOGGIA, A. U. G.; OLIVEIRA, A. M. S. Tecnógeno: um novo campo de estudos das geociências. In: CONGRESSO DA ASSOCIAÇÃO BRASILEIRA DE ESTUDOS DO QUATERNÁRIO, vol. 10, p. 01-04. 2005.

PELOGGIA, A. U. G. Classificação Geológica e Mapeamento de Terrenos Tecnogênicos (Artificiais): estado da arte e análise comparativa. In: $16^{\circ}$ CONGRESSO BRASILEIRO DE GEOLOGIA DE ENGENHARIA E AMBIENTAL, 2018.

PEREIRA, A. A. Mapeamento e caracterização de depósitos tecnogênicos no bairro Batel, Guarapuava - PR. Caminhos de Geografia, v.12, n.40, p.80-90, 2011.

PEREZ FILHO, A.; QUARESMA, C. C. A ação antrópica sobre as escalas temporais dos fenômenos geomorfológicos. Revista Brasileira de Geomorfologia, v.12, n.3, 83-90, 2011.

PEREZ FILHO, A.; QUARESMA, C. C. A fragilidade de terras ocupadas por savana no território paulista - SP. Revista Associação Portuguesa de Geomorfologia, v.3, 245-250, 2006.

PREFEITURA DE PELOTAS. Plano Ambiental de Pelotas. Pelotas: Secretaria de Qualidade Ambiental. 2013. 120p. Disponível em:

<http://www.pelotas.rs.gov.br/qualidadeambiental/plano-municipal/arquivos/PlanoAmbiental-de-Pelotas.pdf>. Acesso em 10 dez. 2018.

SILVA, A. R. E. da; REHBEIN, M. O. Análise e mapeamento geomorfológico da área de influência da Planície Costeira de Pelotas (Rio Grande do Sul). Revista

Brasileira de Geomorfologia, v. 19, n. 3, p. 567-585, 2018.

SILVA, C. S. da. Inundações em Pelotas/RS: o uso de geoprocessamento no planejamento paisagístico e ambiental. 2007. 196 f. Dissertação de Mestrado em Arquitetura e Urbanismo - Universidade Federal de Santa Catarina (UFSC, SC, Brasil).

SILVA, E. C. N.; DIAS, M. B. G.; MATHIAS, D. T. A abordagem tecnogênica: reflexões teóricas e estudos de caso. Quaternaryand Environmental

Geosciences, v. 5, n. 1, 01-11, 2014.

SILVA, M. Impactos ambientais decorrentes da instalação de depósitos tecnogênicos na ilha de Santa Catarina, SC, Brasil. 2013. 108f. Dissertação de Mestrado em Geografia - Universidade Federal de Santa Catarina (UFSC - SC, Brasil).

TER-STEPANIAN, G. Beginning of the Technogene. Bulletin I.A.E.G., v.38, 133-142, 1988. 
TOMAZELLI, L. J.; VILLWOCK, J. A. O Cenozóico no Rio Grande do Sul: Geologia da Planície Costeira. In: Holz, M. \& De Ros, L. F. (org.) Geologia do Rio Grande do Sul. Editora CIGO/UFRGS, Porto Alegre, 2000, p. 375-406.

XAVIER, S. C. O mapeamento geotécnico por meio de geoprocessamento como instrumento de auxílio ao planejamento do uso e ocupação do solo em cidades costeiras estudo de caso para Pelotas (RS). 2010. 261f. Dissertação Mestrado em Engenharia Oceânica - Universidade Federal do Rio Grande (FURG RS Brasil). 